\title{
Terrestrial Isopoda (Crustacea, Oniscidea) from the coasts of Costa Rica, with descriptions of three new species
}

\author{
Stefano Taiti ${ }^{1,2}$, Giuseppe Montesanto ${ }^{3} \&$ José A. Vargas $^{4,5}$ \\ 1. Istituto per lo Studio degli Ecosistemi, Consiglio Nazionale delle Ricerche, Via Madonna del Piano 10, 50019 Sesto \\ Fiorentino (Florence), Italy; stefano.taiti@ise.cnr.it \\ 2. Museo di Storia Naturale dell'Università di Firenze, Sezione di Zoologia "La Specola", Via Romana 17, 50125 \\ Florence, Italy \\ 3. Dipartimento di Biologia, Università degli Studi di Pisa, via A. Volta 4bis, 56126 Pisa, Italy; \\ giuseppe.montesanto@unipi.it \\ 4. Centro de Investigación en Ciencias del Mar y Limnología (CIMAR), Universidad de Costa Rica, 11501-2060, San \\ José, Costa Rica; jose.vargas@ucr.ac.cr \\ 5. Escuela de Biología, Universidad de Costa Rica, 11501-2060, San José, Costa Rica.
}

$$
\text { Received 06-II-2017. Corrected 02-VIII-2017. Accepted 03-I-2018. }
$$

\begin{abstract}
Seven species of terrestrial isopods are recorded from the coasts of the Pacific and Caribbean sides of Costa Rica. Three species (Buchnerillo neotropicalis, Hawaiioscia nicoyaensis and Trichorhina biocellata) are described as new and two species (Tylos niveus and Armadilloniscus cf. caraibicus) are newly recorded from the country. The poorly known species $T$. niveus is also illustrated. At present the total number of terrestrial isopod species recorded from Costa Rica is 30. Interestingly four typical littoral halophilic species (Ligia baudiniana, Tylos wegeneri, T. niveus and A. cf. caraibicus) are present on both the Pacific coast of Costa Rica and on the coasts of the lands encompassed by the Caribbean Sea. With the sole exception of $A$. cf. caraibicus, no morphological differences could be detected from the Pacific and Caribbean populations of those species. Rev. Biol. Trop. 66(Suppl. 1): S187-S210. Epub 2018 April 01.
\end{abstract}

Key words: Crustacea, Isopods, biodiversity, Buchnerillo, Hawaiioscia, Trichorhina, Gulf of Nicoya, Central America.

Up to date, the diversity of Costa Rican terrestrial isopods is poorly known. Only 25 species in 16 genera and 10 families are presently recorded, numbers that are certainly very small for a tropical country like Costa Rica. Many records are very old, mainly dated in the first half of 1900 (Richardson, 1910, 1913; Arcangeli, 1927, 1930, 1957; Van Name, 1936), while only the families Philosciidae and Scleropactidae have been recently revised by Leistikow (1997a, 1997b, 1998, 2000a, b, 2001) and Schmidt (2007). However, all the records come from sporadic collections. Only few records are known for most of the forested areas and only two species (Ligia baudiniana Milne Edwards, 1840 and Tylos wegeneri Vandel, 1952) were reported from the coasts of the country.

This paper deals with recent collections of Oniscidea from both the Pacific and Caribbean coastal areas of Costa Rica, and includes the descriptions of three new species and two new records for the country.

\section{MATERIALS AND METHODS}

The specimens included in this paper have been collected in November 2015 on both 
sandy and rocky coasts of the Pacific side of Costa Rica. Also included are littoral terrestrial isopods deposited in the collection of the Museo de Zoología, Universidad de Costa Rica (MZUCR), San José. Specimens were collected by hand and stored in $75 \%$ ethanol. The geographic co-ordinates of the locations were taken using WGS84 datum. Identifications are based on morphological characters. For each new species the material examined, description, etymology and remarks are given. For each species already recorded from Costa Rica the bibliographic references, material examined, distribution and remarks (when necessary) are included. Some poorly known species have been illustrated to facilitate future recognition. The taxa are illustrated with figures prepared with the aid of a camera lucida mounted on Wild M5 and M20 microscopes and digitally drawn using the method by Montesanto $(2015,2016)$. For some species pictures were taken with a Scanning Electron Microscope Hitachi S-3700N.

Abbreviations: $\mathrm{BM}=$ The Natural History Museum, London, MZUCR = Museo de Zoologia, Escuela de Biologia, Universidad de Costa Rica, San José, Costa Rica, MZUF = Museo di Storia Naturale dell'Università, Sezione di Zoologia "La Specola", Florence, Italy.

\section{SYSTEMATIC ACCOUNT}

Family Ligiidae Leach, 1814

Genus Ligia Fabricius, 1798

Ligia baudiniana Milne Edwards, 1840

Ligia (Hirtiligia) baudiniana;

Schultz, 1974: 167, figs 122-3.

Ligia baudiniana; Leistikow, 1997a: 1417,

figs. 2-7; Leistikow \& Wägele, 1999: 2;

Schmalfuss, 2003: 141.

Material examined: $1 \hat{\jmath}, 2$ 우 (MZUF 9684), Playa Pita, S of Tárcoles, Puntarenas, 9'44'32.9" $\mathrm{N}$ and 84'37'53.0" $\mathrm{W}$, under logs on a sandy beach, 27.XI.2015, leg. S. Taiti, R. Vargas \& J.A. Vargas; 1 § (MZUCR 2580-02), Isla San José, Islas Murciélago,

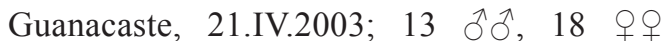
(MZUCR 2865-01), Reserva de Cabo Blanco, sector San Miguel, 10.VII.1994, leg. L.A. Mena; 1 ㅇ (MZUCR 3154-03), Playa Blanca, Punta Morales, sandy beach, 29.XI. 2011, leg. J.A.Vargas \& J. Sibaja, det. R. Vargas; 1 đ (MZUCR 1870), Isla Cabuya, Cabo Blanco, 16.XII.1992, leg. L. Mena; 6 우 (MZUCR 2069-01), Manuel Antonio, Quepos, Aguirre, Puntarenas, 3.IX.1984, leg. B. Morera, det. A. Leistikow; 1 ô, 1 우 (MZUCR 2070-01), same locality, 2.IX.1984, leg. B. Morera, det. A. Leistikow; 3 ภิ Guanacaste, date?, leg. O. Breedy.

Costa Rican records: Puntarenas (Schultz, 1974). Puntarenas Prov., Corcovado, Punta Salsipuedes; Limón Prov., Punta Cahuita; Isla San Lucas (Leistikow, 1997a).

Distribution: Atlantic and Pacific shores of the Americas from Florida to Brazil and from California to Ecuador, including Galapagos Islands (Schmalfuss, 2003).

Remarks: At present, this is the only species of Ligia recorded from both coasts of Costa Rica. The species has been fully redescribed and illustrated by Leistikow (1997a).

Family Tylidae Milne Edwards, 1840

Genus Tylos Audouin, 1826

Tylos wegeneri Vandel, 1952

Tylos wegeneri; Schultz, 1983: 682; Leistikow \& Wägele, 1999: 4; Schmalfuss \& Vergara, 2000: 10; Schmalfuss, 2003: 324.

Costa Rican records: Puntarenas (Schultz, 1983).

Distribution: USA: Florida; Costa Rica: Pacific Coast; Lesser Antilles: Saint Martin; Trinidad; Tobago; Venezuela (Schmalfuss, 2003).

Remarks: Tylos wegeneri was recorded from Puntarenas by Schultz (1983). This is the only record of this species for the Pacific coast, while the species seems to be widespread in the Caribbean Sea. However, no records from the Caribbean coast of Costa Rica are known. For a description and figures of this species see Vandel (1952) and Schultz (1970). 
Tylos niveus Budde-Lund, 1885

Figs. 1, 2

Material examined: $3 \hat{\jmath} \widehat{\jmath}(\mathrm{MZUCR}$ 2867-02), Boca Coronado, manglar TérrabaSierpe, 3.IX.2008, leg. L. Rolier Lara.

Distribution: Florida; Bahamas; Bermudas; Cuba; Tobago; Bonaire; Dominica; Curazao; Virgin Islands; Puerto Rico; Mexico; Belize; Venezuela; Colombia; Brazil
(Schmalfuss, 2003; Carpio-Díaz, López-Orozco, Herrera-Medina, Navas-S., \& Bermúdez, 2016). New record for Costa Rica.

Remarks: The main characters of this species are illustrated in Figs. 1 and 2 to confirm its identification and facilitate future recognition. For a complete list of synonyms of this species see Schmalfuss \& Vergara (2000). This is the first record for the Pacific coast.

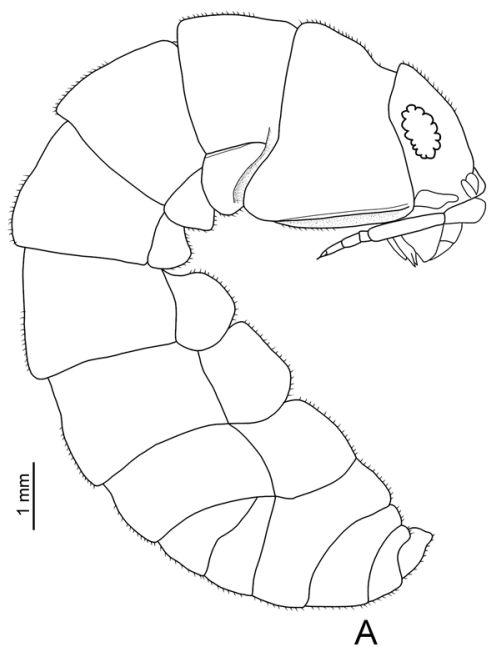

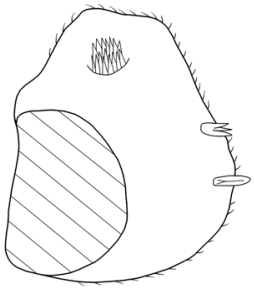

$\mathrm{F}$

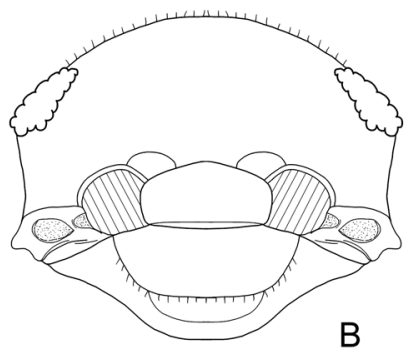

B
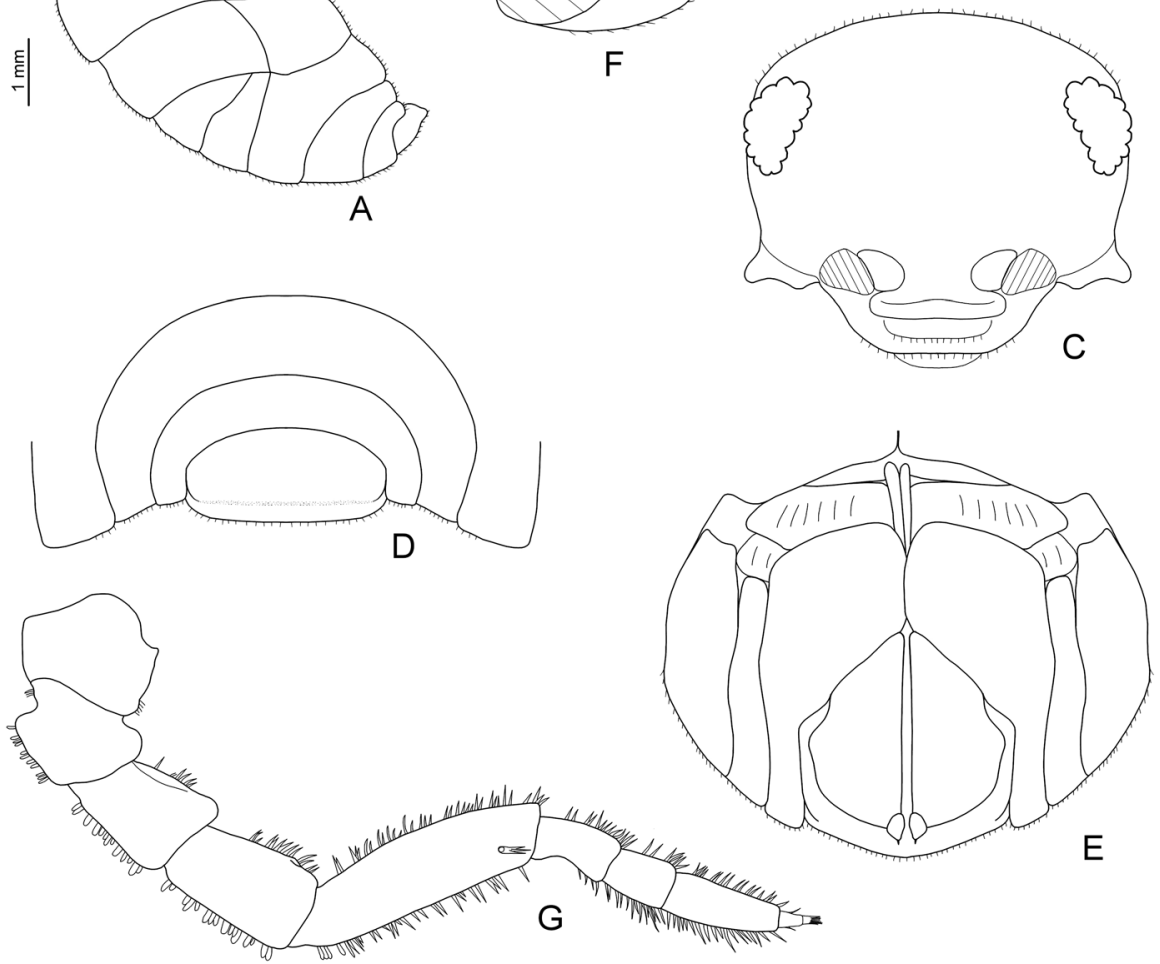

Fig. 1. Tylos niveus Budde-Lund, 1885, ô from Boca Coronado. A. Adult specimen in lateral view; B. Cephalon, frontal; C. Cephalon, dorsal; D. Pleonites 4, 5 and telson, dorsal; E. Pleon and uropods, ventral;. F. Antennula; G. Antenna. 

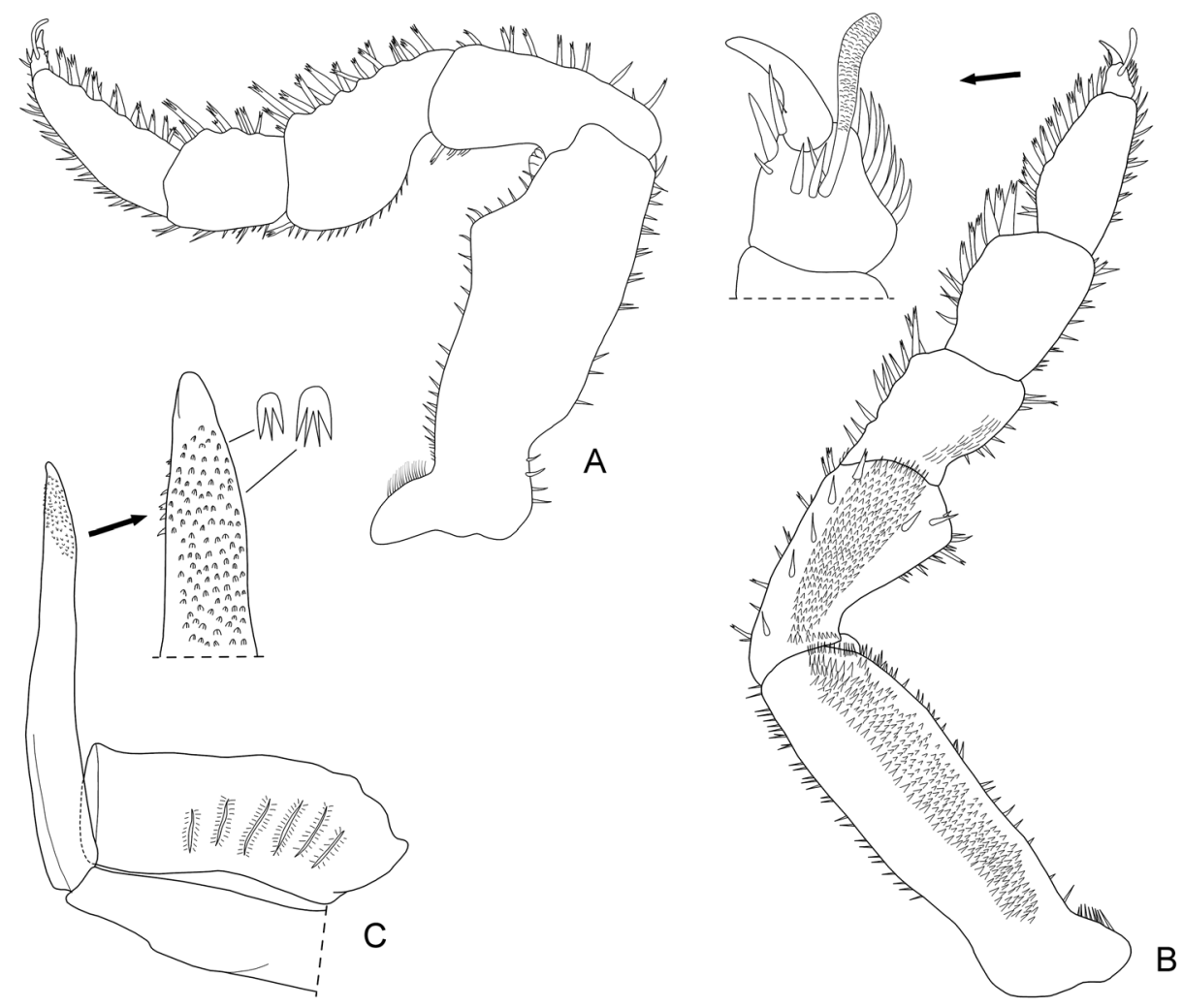

Fig. 2. Tylos niveus Budde-Lund, 1885, ô from Boca Coronado. A. Pereopod 1; B. Pereopod 7; C. Pleopod 2.

Incertae sedis

Genus Buchnerillo Verhoeff, 1942

Buchnerillo neotropicalis $\mathrm{n}$. sp.

Figs. 3-6

Holotype: $\hat{o}$ (MZUF 9685), Playa Pita, S of Tárcoles, Puntarenas, 944'32.9”' $\mathrm{N}$ and $84^{\circ} 37^{\prime} 53.0^{\prime \prime} \mathrm{W}$, sandy beach, under logs, 27.XI.2015, leg. S. Taiti, J.A.Vargas \& R. Vargas.

Paratypes: 6 우 (MZUF 9685), 4 우우 (MZUCR-3529-04), same data as holotype.

Additional material: 2 우 used for scanning microscope analysis, same data as holotype.

Description: Maximum size: o $1.5 \mathrm{x}$ $0.8 \mathrm{~mm}$; + 1.9 x $1 \mathrm{~mm}$. Colour pale. Animals able to roll up into a perfect ball (Fig. 3A, B). Dorsal body surface covered with tubercles disposed as follows: five rows on cephalon; three rows on pereonite 1 ; two rows on pereonites 2 - 7; two rows on pleonites 3 and 4; one row on pleonite 5; four tubercles on telson; each dorsal tubercle apically with one scaleseta (Fig. 3C, D). Cephalon (Fig. 4A, B) with frontal shield grooved, upper margin regularly convex, lower margin sinuous on both sides; eye consisting of 4 ommatidia. Pereonite 1 (Fig. 4B) with semicircular hollow on anterior margin in which ocular lobe fits; postero-lateral corner with schisma, inner lobe rounded and distinctly protruting backwards; posterior margin straight. Pereonites 2 - 4 with triangular epimera. Pereonites $5-7$ with quadrangular epimera. Pleonites 1 and 2 not visible in dorsal view, pleonite 3 with no visible epimera, pleonite 4 twice as long as pleonite 5 (Fig. 4C). Telson (Fig. 4D) semicircular. Antennula (Fig. 

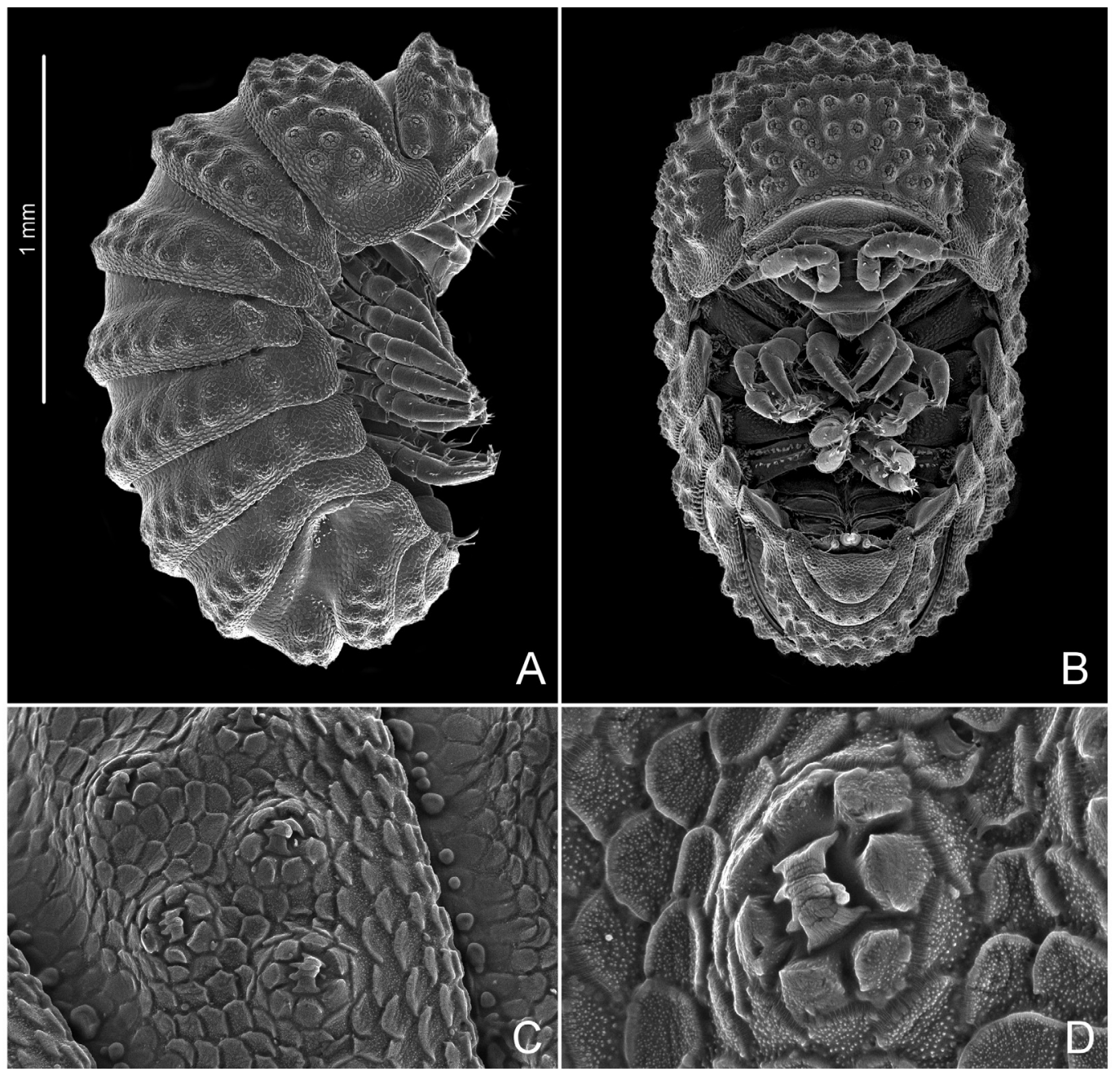

Fig. 3. Buchnerillo neotropicalis n. sp. + from Playa Pita. A. Adult specimen in lateral view; B. Adult specimen in ventral view; C. Dorsal tubercles with scale-setae; D. Dorsal scale-seta.

5A) of two articles; first article about twice as long as second; second article with two large petaliform aesthetascs at apex. Antenna (Fig. 5B) short and thickset; flagellum of 3 articles, second article bearing 2 aesthetascs. Mandibles (Fig. 5C, D) with molar penicil semidichotomized, left mandible with $2+1$ free penicils; right mandible with $1+1$ free penicils. Maxillula (Fig. 5E) inner branch with a few setae at apex but no penicils; outer branch with $4+4$ teeth, all apically entire, and stalk among outer group of teeth. Maxilla (Fig. 5F) with triangular distal part bearing thick setae. Maxilliped (Fig. $5 \mathrm{G})$ endite triangular with two subapical stout setae and apical penicil; palp with two setae on first article. Pereopods (Fig. 6A) with one large trifid seta on carpus, long setose dactylar seta and flagelliform ungual seta; pereopod 7 with water conducting system on basis. Uropod (Fig. $5 \mathrm{H}$ ) protopod quadrangular; endopod much longer than exopod, both with very long apical setae.

Male: Pereopod 7 (Fig. 6B) with no distinct modifications; ischium sternal margin 

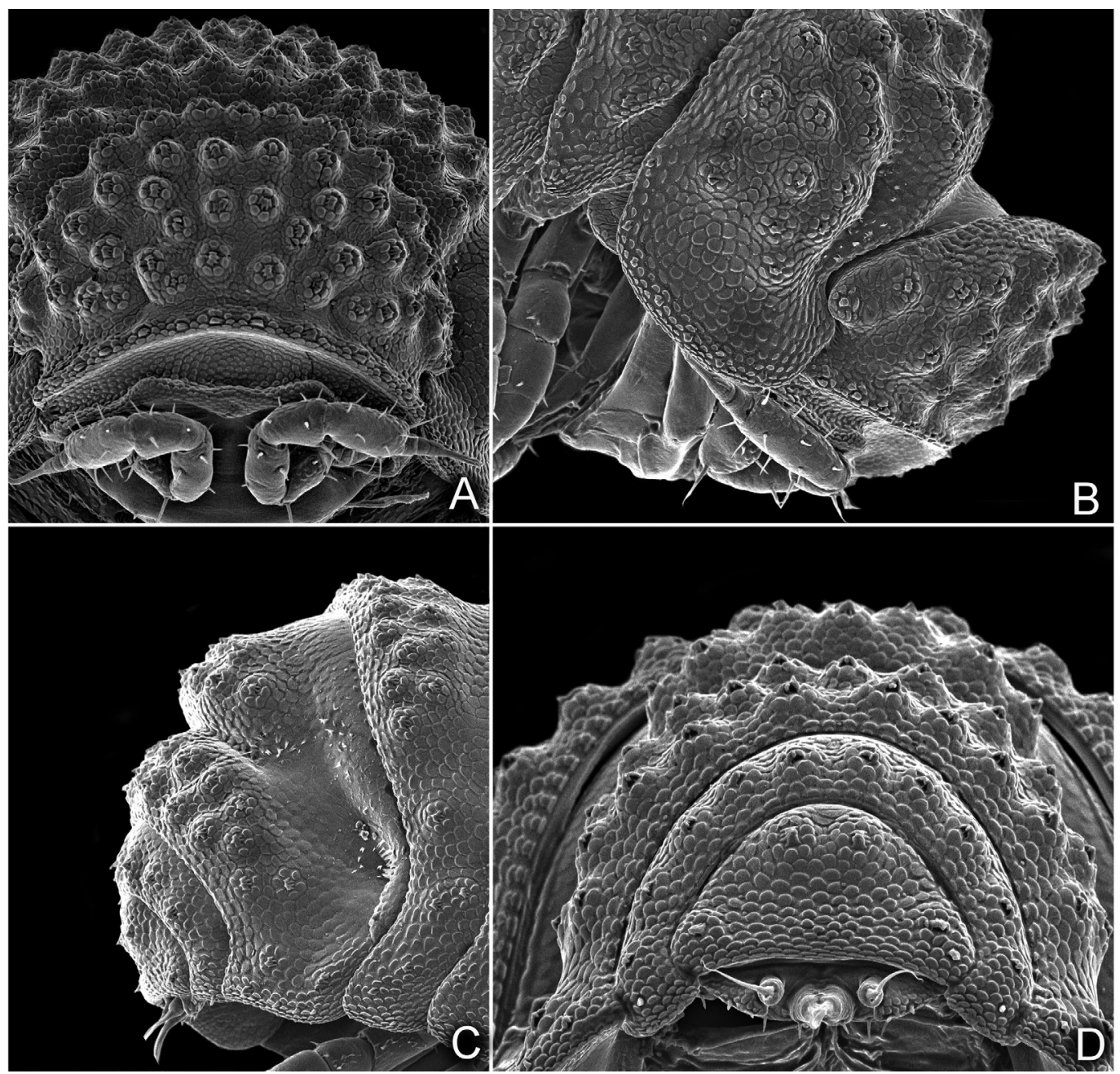

Fig. 4. Buchnerillo neotropicalis n. sp. of from Playa Pita. A. Cephalon, dorsal; B. Cephalon, lateral; C. Pereonite 7, pleon and telson, lateral; D. Pleon and telson, dorsal.

straight. Pleopod 1 (Fig. 6C) exopod small, ovoidal; endopod very elongated with distal part triangular, straight. Pleopod 2 (Fig. 6D) exopod triangular with one distal hairy seta and some short thin setae on inner and outer margin; endopod of two articles, distal article flagelliform, about 5 times longer than first. Ppleopod 3 - 5 exopods as in Fig. 6E-G.

Etymology: The name of the species refers to the localities of collection of the species, the Neotropical Region.
Remarks: The new species is included in Buchnerillo since it shows all the characters of the genus: small size; animal able to toll up into a perfect ball; endoantennal conglobation; dorsal surface tuberculated; cephalon with a wide frontal shield; pleonite 3 with epimera reduced; telson semicircular covering the uropods in dorsal view; antenna short and stout with a flagellum of three articles; male pleopod 2 with distal article flagelliform. Up to date, only two species of Buchnerillo are known: B. litoralis 
Verhoeff, 1942 and B. oceanicus Ferrara, 1974. The former is known from the shores of the Mediterranean Sea and Madeira (Schmalfuss, 2003); a record of a female specimen from Florida Keys (Paoletti \& Stinner, 1989) is very doubtful and the identification needs confirmation. The latter is presently known from Somalia (Ferrara, 1974) and the Maldives (Taiti, 2014). Buchnerillo neotropicalis n. sp. differs from both species in the presence of a schisma on the pereonite 1 with inner lobe distinctly protruding backwards, whereas in $B$. litoralis and $B$. oceanicus a small rounded ventral lobe is present at the postero-lateral corners,

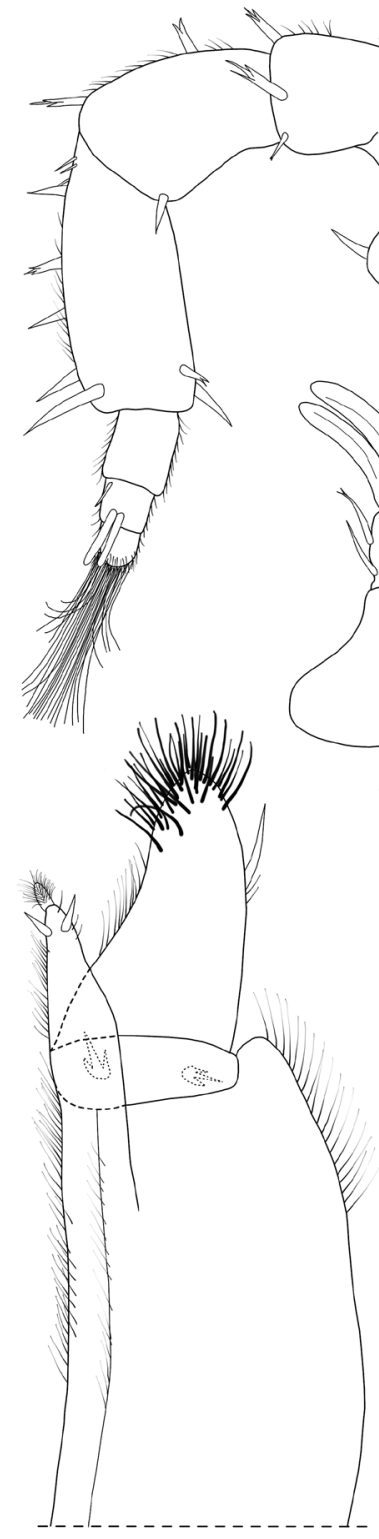

G
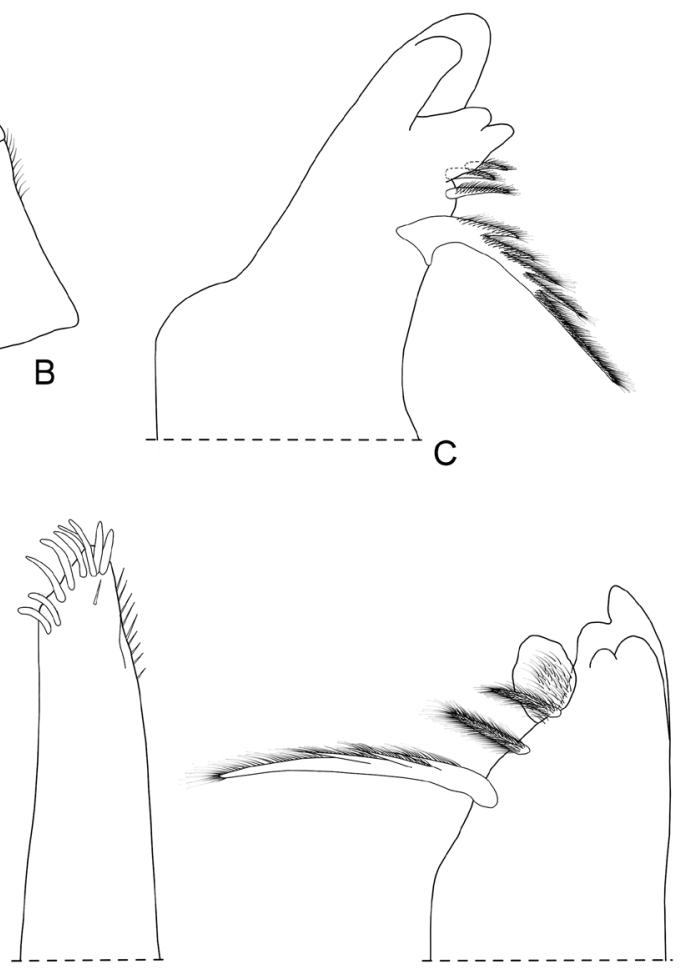

$\mathrm{F}$

D
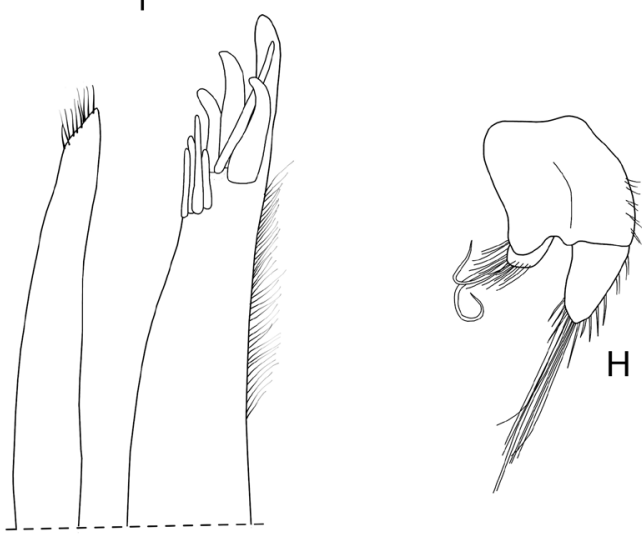

E

Fig. 5. Buchnerillo neotropicalis n. sp. \& from Playa Pita. A. Antennula; B. Antenna; C. Left mandible; D. Right mandible; E. Maxillula; F. Maxilla; G. Maxilliped; H. Uropod. 
not protruding backwards. It also differs from B. litoralis (see redescription in Vandel, 1960) in having the cephalon with frontal shield grooved, larger eyes (4 ommatidia instead of 1 - 2), dorsal tubercles more prominent and male pleopod 1 endopod with distal part thicker and straight; from B. oceanicus in the frontal shield with lower margin sinuous on both sides instead of regularly curved.

The systematic position of genus Buchnerillo is still uncertain. It was included by Vandel (1960) in the section Synocheta and family
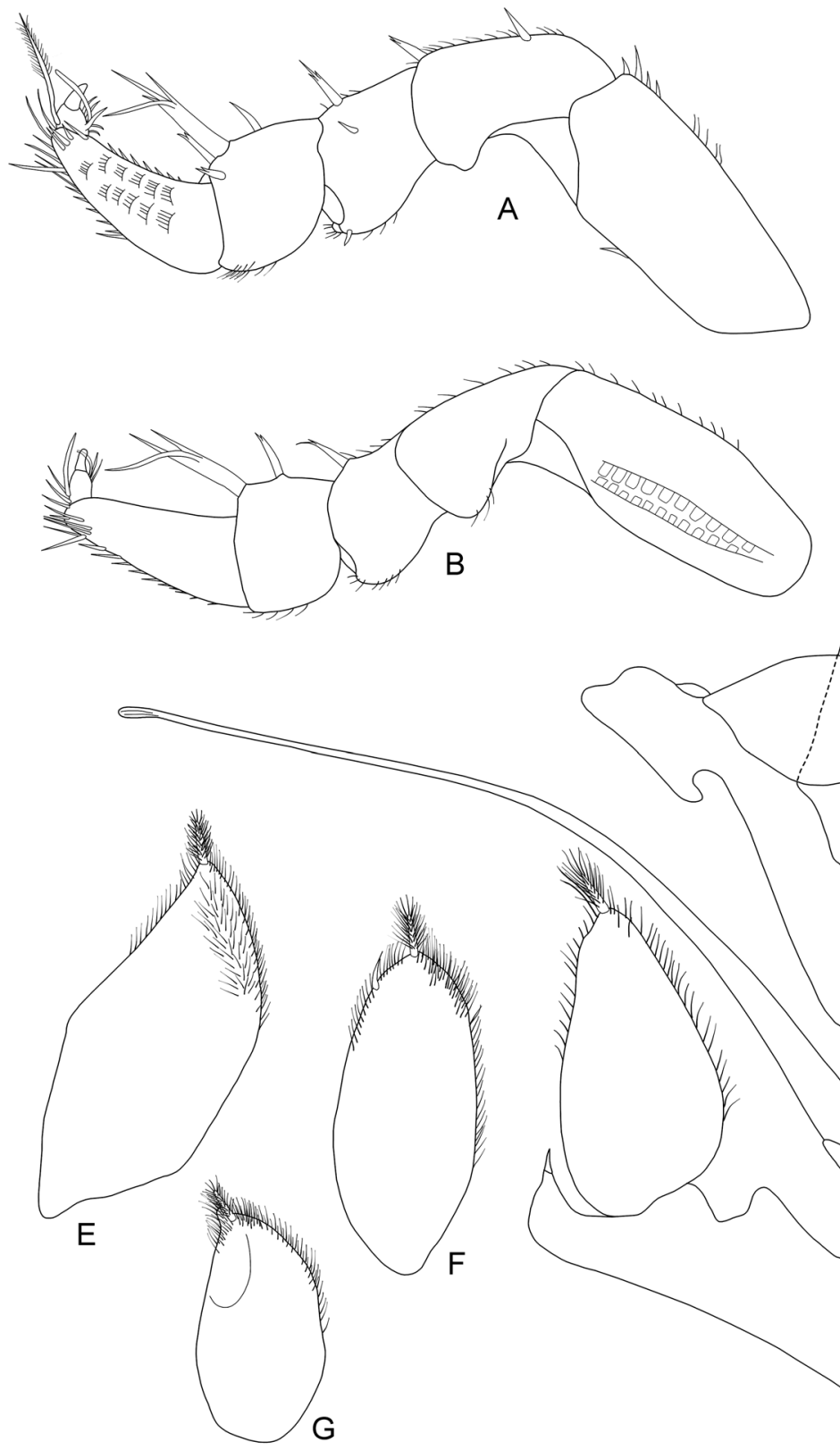 . 
Buddelundiellidae (now a subfamily of Trichoniscidae). Tabacaru (1993) recognized that the genus could not belong to the Synocheta and Schmalfuss (2003) included it into the higher Oniscidea (the Crinocheta) and hypothesised that the genus might belong to the family Detonidae, close to the genus Armadilloniscus. According to the maxillular endite bearing only some apical setae without penicils, it might also be related to the family Olibrinidae. However, since no safe conclusion can be reached with morphological characters, we still maintain the genus as incertae sedis as proposed by Taiti \& Ferrara (1991). A molecular analysis might be useful to clarify the family placement of Buchnerillo.

Family Detonidae Budde-Lund, 1904 Genus Armadilloniscus Uljanin, 1875 Armadilloniscus cf. caraibicus Paoletti \& Stinner, 1989

Fig. 7

Material examined: $1 \uparrow$ (MZUF 9687), 1 o used for scanning microscope analysis, Playa Pita, S of Tárcoles, Puntarenas, $9^{\circ} 44^{\prime} 32.9^{\prime \prime} \mathrm{N}$ and $84^{\circ} 37^{\prime} 53.0^{\prime \prime} \mathrm{W}$, beach under logs, 27.XI.2015, leg. S. Taiti, J.A. Vargas \& R. Vargas.

Distribution: Venezuela (Paoletti \& Stinner (1989). New record for Costa Rica.

Remarks: The two female specimens here examined are morphologically very similar to Armadilloniscus caraibicus described by Paoletti \& Stinner (1989) for the Caribbean coast of Venezuela. The main characters of the Costa Rican specimens are shown in Fig. 7. They show the same disposition of dorsal tubercles as those from Venezuela (see Figs. 10 and 11 in the original description by Paoletti \& Stinner, 1989 and Figs. 32 and 33 in Schmidt, 2002) but they are less developed. Since we have examined only 2 females, we only tentatively identify them as $A$. cf. caraibicus.
Family Philosciidae Kinahan, 1957

Genus Hawaiioscia Schultz, 1973

Hawaiioscia nicoyaensis n. sp.

Figs. 8-11

Holotype: $\widehat{\sigma}$ (MZUCR-3529-05), Playa Pita, south of Tárcoles, Puntarenas, 9०44'32.9" $\mathrm{N}$ and $84^{\circ} 37^{\prime} 53.0^{\prime \prime} \mathrm{W}$, beach under logs, 27.XI.2015, leg. S. Taiti, J.A. Vargas \& R. Vargas.

Paratypes: 5 ふぇ, 8 우우 (MZUCR-352906), 5 ठิ่人, 15 우, 12 juvs (MZUF 9688), same data as holotype.

Additional material examined: $1 \curvearrowright, 1$, used for scanning microscope analysis, same data as holotype.

Description: Maximum size: $\hat{\jmath}, 5.8 \times 2.5$ $\mathrm{mm}$;,$+ 6 \times 3 \mathrm{~mm}$. Dorsum dark brown with the usual muscle spots; a large pale spot at base of pereon epimera. Body flat, ovoidal, with pleon narrower than pereon (Fig. 8A, B). Dorsal body surface finely granulated with small triangular scale-setae (Fig. 9A). Pereonites with no sulcus marginalis, gland pores absent. Noduli laterales small (Fig. 9B) but clearly visible, inserted on small tubercles and disposed as follows: two on cephalic vertex, one per side on pereonites 1 - 6 with that on fourth pereonite much more distant from lateral margin of segment, and two per side on pereonite 7 (Fig. 9C-E). Cephalon (Figs. 8C, 9E) with short triangular lateral lobes not protruding frontwards compared with obtuse middle lobe; frontal and supra-antennal lines absent; eyes consisting of 19 - 20 ommatidia. Pleon epimera reduced but with distinct posterior points (Fig. 8A, D). Telson (Fig. 8D) triangular, about twice as wide as long, with slightly concave sides and broadly rounded apex. Antennula (Fig. 9F) of 3 articles, second article slightly shorter than first and third; third article bearing two rows of 3 and 5 aesthetascs each, and 2 apical aesthetascs. Antenna (Fig. 9G) long and thin, reaching back rear margin of pereonite 3; flagellum slightly longer than fifth 


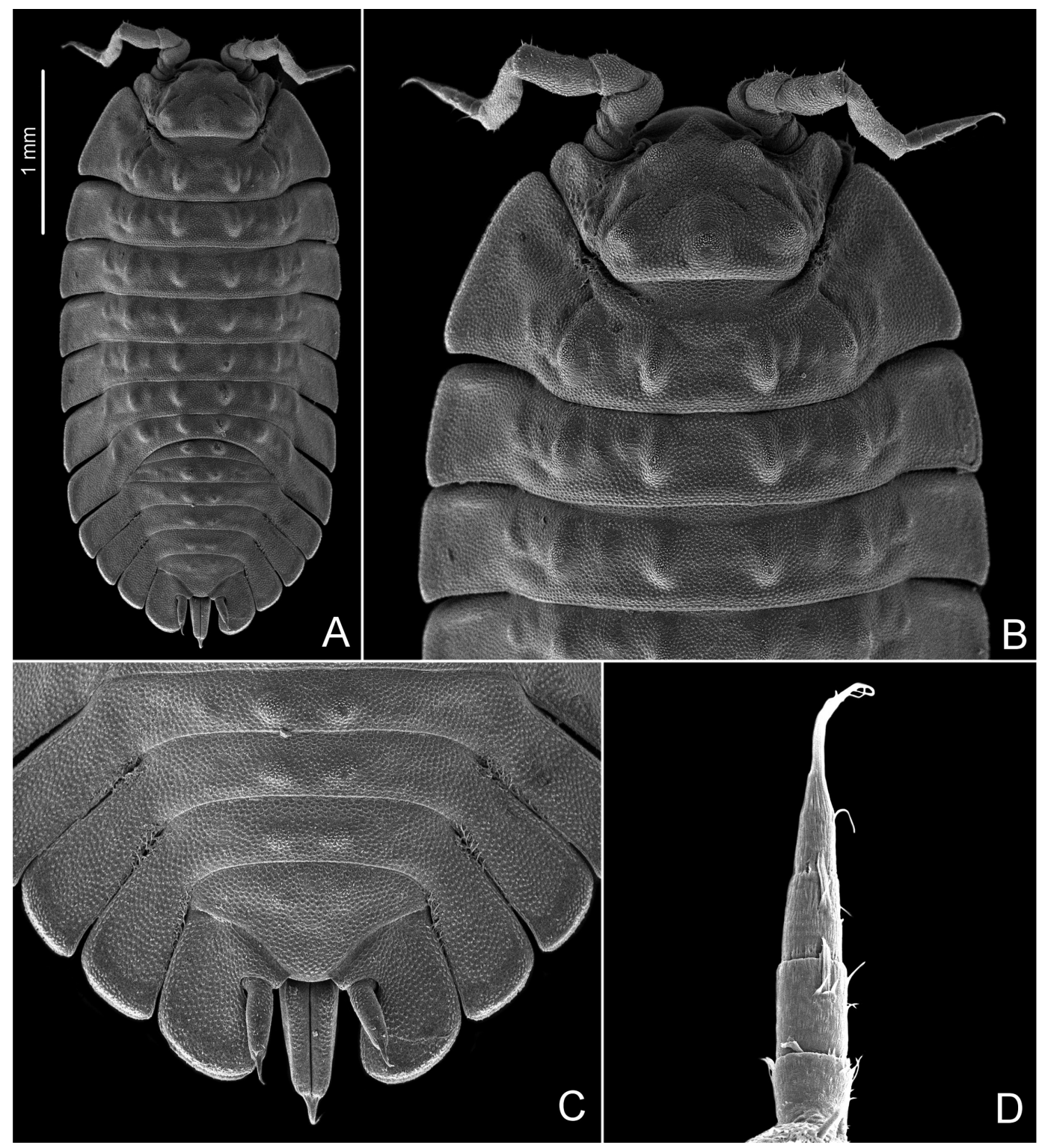

Fig. 7. Armadilloniscus cf. caraibicus Paoletti \& Stinner, 1989. ㅇ from Playa Pita. A. Adult specimen in dorsal view; B. Cephalon and pereonites 1-3, dorsal; C. Pleonites 3-5, telson and uropods, dorsal; D. Antennal flagellum.

peduncular article, first flagellar article as long as third, second article shortest; one row of 1 - 2 and 3 aesthetascs on each second and third article. Mandibles (Fig. 10A, B) with molar penicil semidichotomized, i.e. consisting of 4 setae on a common stem; left mandible with $2+1$ and right mandible with $1+1$ free penicils. Maxillula (Fig. 10C) outer branch with $4+6$ teeth, all simple and stalk among the outer teeth; inner branch with two stout subequal penicils. Maxilla (Fig. 10D) apically setose and bilobate. Maxilliped (Fig. 10E) endite apically setose and bearing large penicil at medial corner, proximal article of palp bearing 2 strong setae. Pereopods with flagelliform dactylar seta apically slightly enlarged; ungual seta 

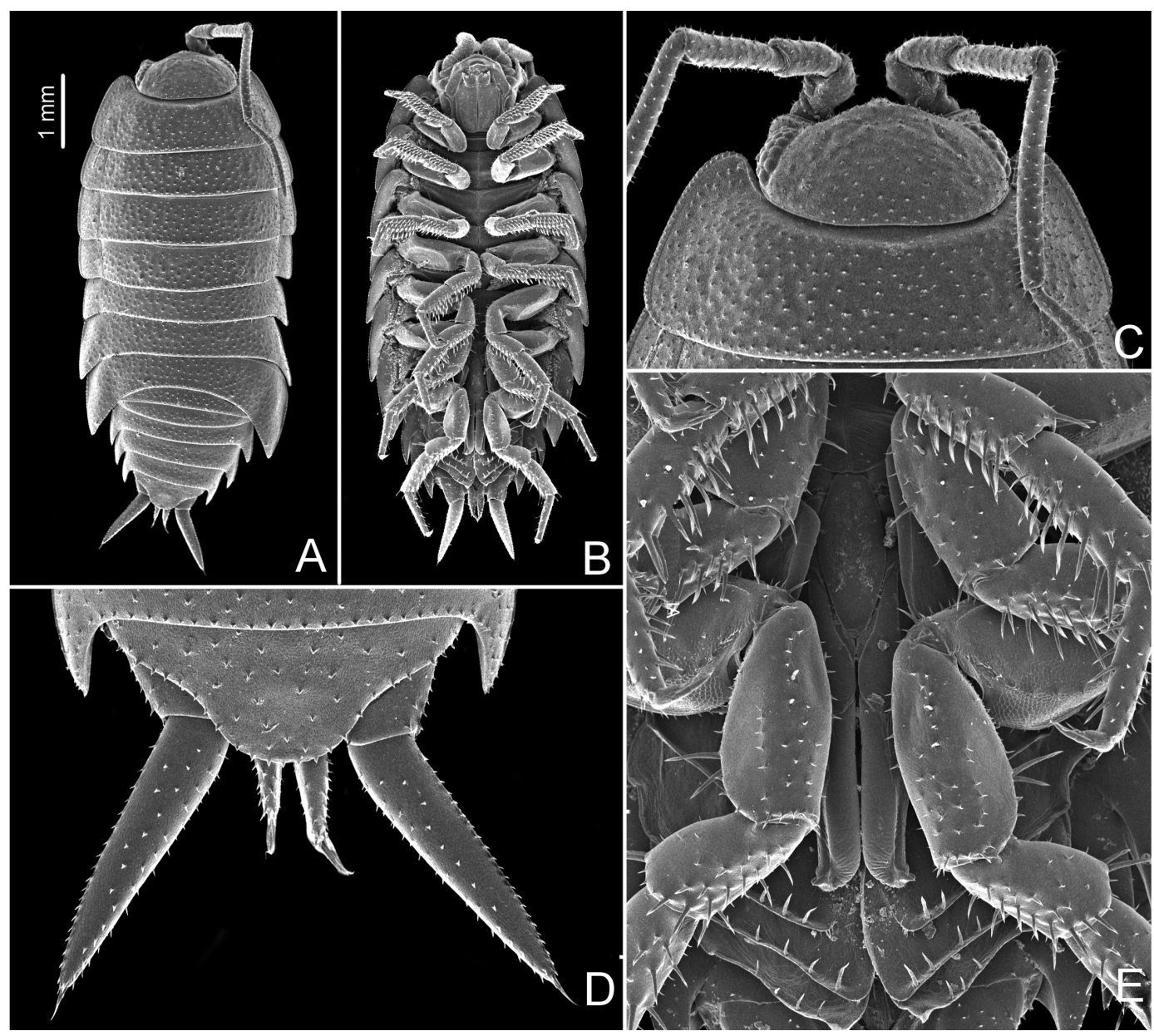

Fig. 8. Hawaiioscia nicoyaensis n. sp. specimens from Playa Pita. A. Adult female in dorsal view; B. Adult male in ventral view; C. Cephalon and pereonite 1, dorsal ( + ); D. Pleonite 5, telson and uropods, dorsal (१); E. Pleon, ventral (đ)).

flagelliform almost reaching tip of outer claw (Fig. 10F). Pleopodal exopods with no trace of respiratory structures. Uropodal protopod grooved on outer margin; insertion of endopod slightly proximal to that of exopod.

Male: Pereopods 1 - 4 (Figs. 8B, 10F) merus and carpus with a brush of trifid spines on sternal margin. Pereopod 7 (Figs. 8E, 11A) ischium with sternal margin slightly convex in middle. Genital papilla as in Fig. 11B. Pleopod 1 (Fig. 11C) exopod cordiform, with broadly rounded apex; endopod with thickset distal part, with bilobed apex. Pleopod 2 (Fig. 11D) exopod triangular, with straight outer margin and very convex medial margin, and bearing 4 setae on outer margin near apex. Pleopods 3 - 5 exopod as in Fig. 11E-G.

Etymology: The name of the species refers to the Gulf of Nicoya, where Playa Pita is located.

Remarks: The new species is included in the genus Hawaiioscia since all the most important characters (number and position of noduli laterales, maxillular teeth, penicil on maxillipedal endite, uropod and shape of male pleopod) correspond to the definition of that genus (see diagnosis in Taiti \& Howarth 1997). The genus Hawaiioscia comprises five species from the Hawaiian Islands and Easter Island (Schultz 1973; Taiti \& Howarth 1997; Taiti \& Wynne, 


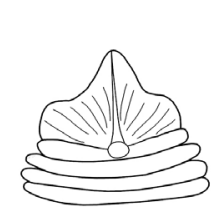

A

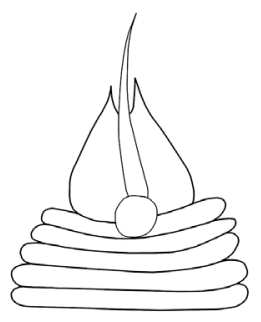

B

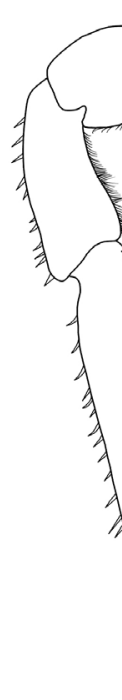

Fig. 9. Hawaiioscia nicoyaensis n. sp. ㅇ from Playa Pita. A. Dorsal scale-seta; B. Nodulus lateralis; C. B/c and d/c coordinates of noduli laterales; D. Pereonites showing position of noduli laterales; E. Cephalon, frontal;

2015): H. parvituberculata Schultz, 1973 from Maui, H. microphthalma Taiti \& Howarth, 1997 from Oahu, H. paeninsulae Taiti \& Howarth, 1997 from Molokai, H. rotundata Taiti \& Howarth, 1997 from Kauai, and H. rapui Taiti \& Wynne, 2015 from Easter Island. The Hawaiian

\section{F. Antennula; G. Antenna.}
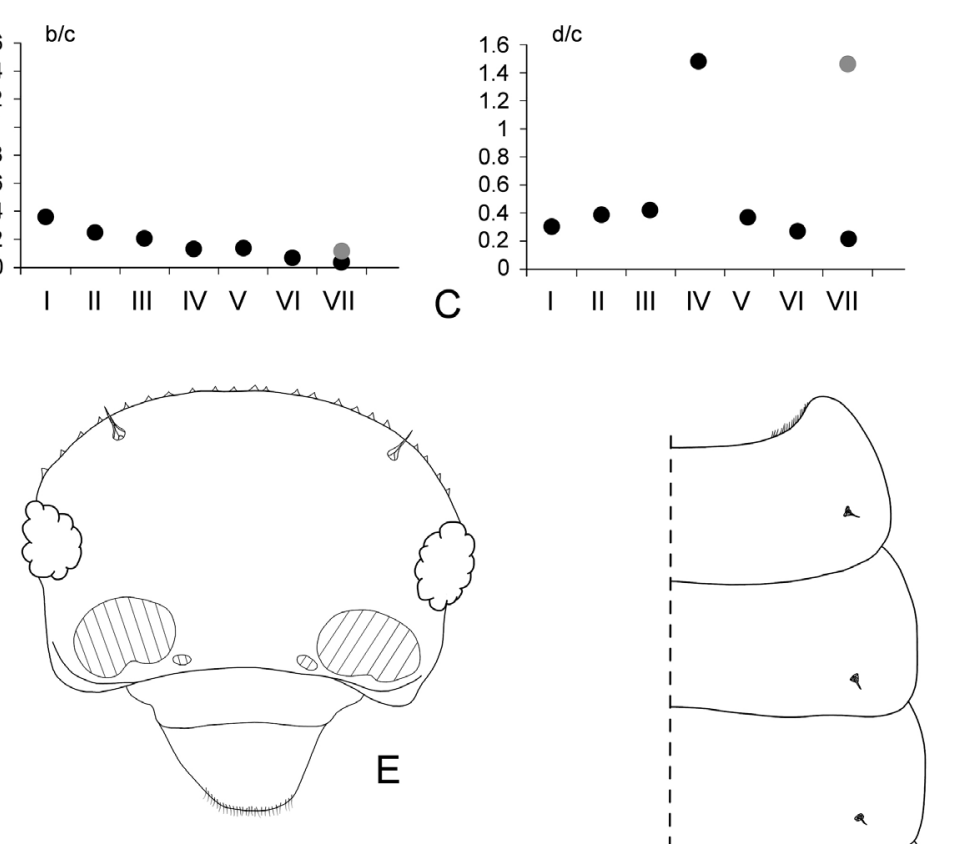

G

species are all cave-dwelling and show troglomorphic traits, such as body depigmentation and eye reduction, while $H$. rapui inhabits cave entrances and does not show distict troglomorphic traits. Hawaiioscia nicoyaensis is the only littoral halophilic species known so far. The 

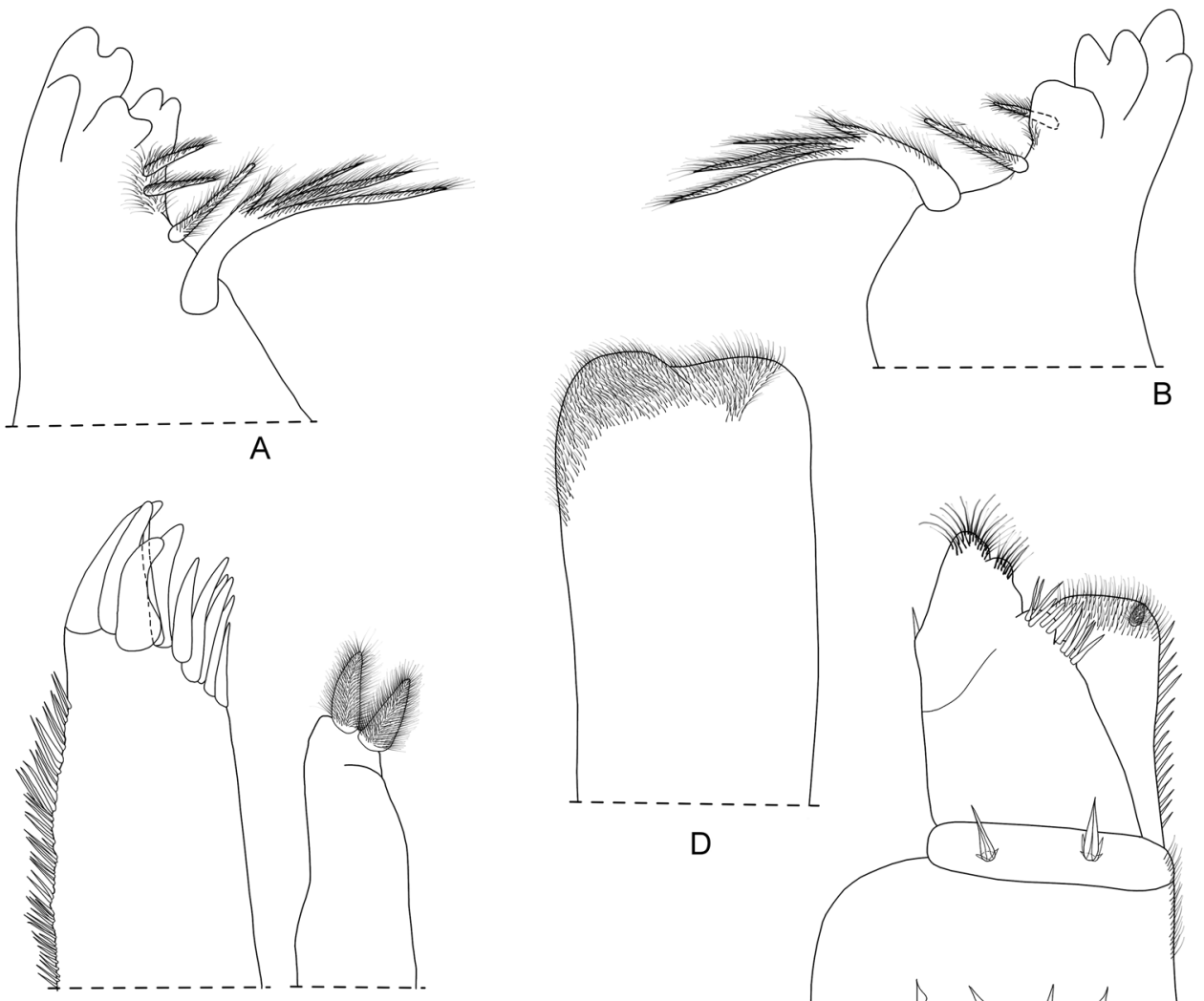

C
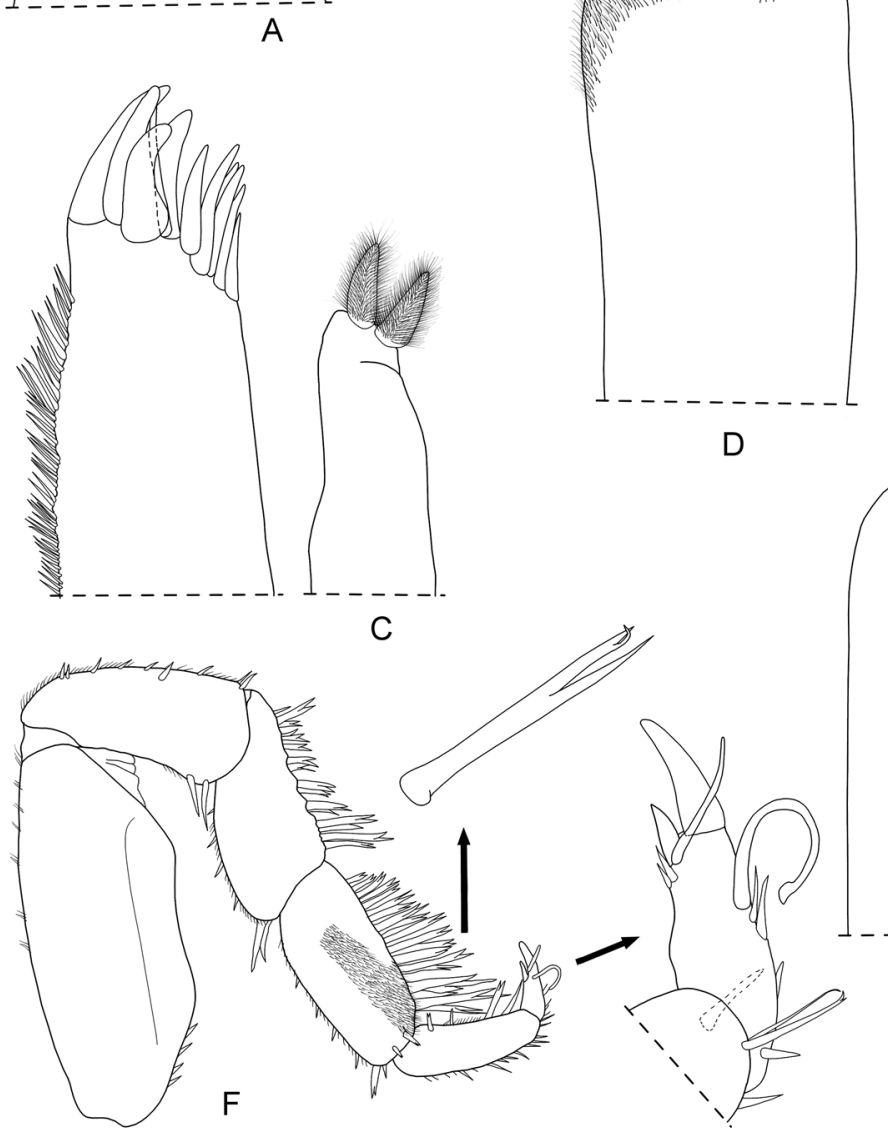

B

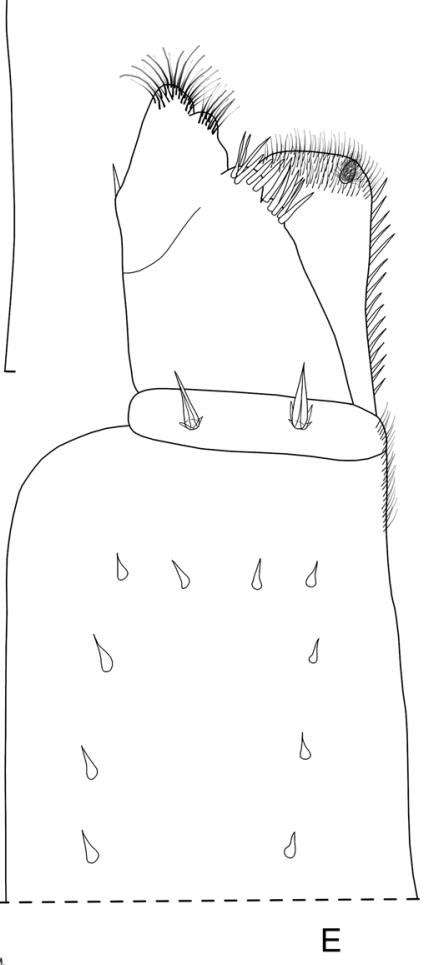

Fig. 10. Hawaiioscia nicoyaensis n. sp. đ̂ from Playa Pita. A. Left mandible; B. Right mandible; C. Maxillula; D. Maxilla; E. Maxilliped; F. Pereopod 1. 


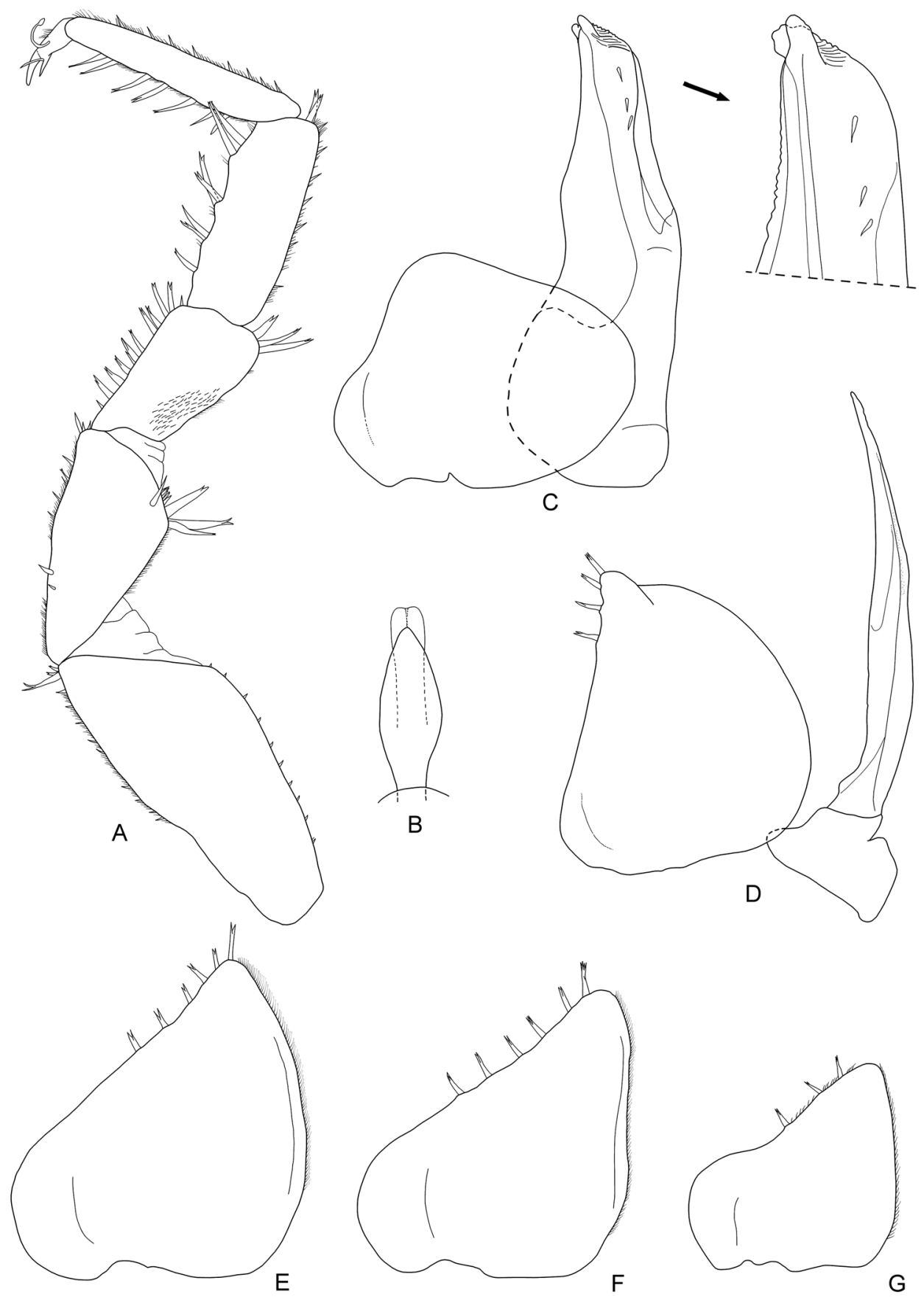

Fig. 11. Hawaiioscia nicoyaensis n. sp. §̋ from Playa Pita. A. Pereopod 7; B. Genital papilla; C. Pleopod 1; D. Pleopod 2; E. Pleopod 3 exopod; F. Pleopod 4 exopod; G. Pleopod 5 exopod. 
new species is readily distinguishable from the Hawaiian species by the pigmented body, the eye well developed and in having the molar penicil of the mandible semidichotomized, instead of simple. For this last character, the new species shows closest affinities with $H$. rapui from which it mainly differs in having larger eyes (19 - 20 instead of 8 ommatidia) and in the shape of the male pleopods 1 and 2 .

Family Platyarthridae Verhoeff, 1949

Genus Trichorhina Budde-Lund, 1908

Trichorhina biocellata $\mathrm{n}$. sp.

Figs. 12-16

Holotype: đิ (MZUCR-3529-01), Playa Pita, S of Tárcoles, Puntarenas, 944'32.9" $\mathrm{N}$ and $84^{\circ} 37^{\prime} 53.0^{\prime \prime} \mathrm{W}$, beach under logs, 27.XI.2015, leg. S. Taiti, R. Vargas \& J.A. Vargas.

Paratypes: 15 ठึ, 25 q + , 8 juvs (MZUF 9693), same data as holotype; 14 ऽึग, 17 우 (MZUCR-3529-02), same locality and date, leg.

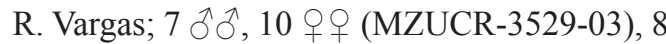
ふึ่, 13 우우 (MZUF 9694), Bahia de Caldera, Puntarenas, 9'55'26.7' $\mathrm{N}$ and 84'42'53.7' $\mathrm{W}$, beach under logs, 27.XI.2015, leg. S. Taiti, R. Vargas \& J.A. Vargas; 2 ठิ ठૈ (MZUF 9695), Manuel Antonio, Playa Espadilla, Puntarenas, 9²3'19" $\mathrm{N}$ and $84^{\circ} 08^{\prime} 48^{\prime \prime} \mathrm{W}$, beach margin, under dead wood, 18.VII.2013, leg. S. Taiti.

Additional material examined: $1 \hat{\sigma}, 1$, used for scanning microscope analysis, same data as holotype.

Description: Maximum size: $\hat{\jmath}, 3.5 \mathrm{x}$ $1.5 \mathrm{~mm}$; +, $3.2 \times 1.5 \mathrm{~mm}$. Dorsum pale brown. Body flat, ovoidal, without interruption between pereon and pleon (Fig. 12A, B). Dorsal body surface covered with spatuliform scale-setae (Fig. 12C). Pereonites with no sulcus marginalis, gland pores absent. Noduli laterales small (Fig. 14A, C), inserted on posterior margin of pereonites, one per side on pereonites $1-6$ and two per side on pereonite 7. Cephalon (Figs. 12D, 14B) with short rounded lateral lobes not protruding frontwards compared with obtuse middle lobe; frontal and supra-antennal lines absent; eyes consisting of two ommatidia of same size (Fig. 13A). Pleon epimera well developed, falciform, directed backwards (Fig. 13B). Telson (Fig.13B) triangular, about twice as wide as long, with slightly concave sides and narrowly rounded apex. Antennula (Fig. 14D) of 3 articles, second article much shorter than first and third; third article bearing tuft of about 8 aesthetascs at apex. Antenna (Figs. $13 \mathrm{C}, 14 \mathrm{E})$ short, reaching back rear margin of pereonite 2; flagellum as long as fifth peduncular article, second flagellar article almost 3 times longer than first, bearing 2 aesthetascs. Mandibles (Fig. 14F, G) with molar penicil semidichotomized, i.e. consisting of $3-4$ setae on a common stem; left mandible with $2+1$ and right mandible with $1+1$ free penicils. Maxillula (Fig. 14H) outer branch with $4+5$ (4 slightly cleft) teeth; inner branch with two thin subequal penicils. Maxilla (Fig. 14I) distinctly bilobed, outer lobe slightly smaller than inner lobe, bearing a row of sensilla. Maxilliped (Fig. 15A) endite apically with 2 triangular setae, proximal article of palp bearing 2 strong setae. Pereopods with flagelliform dactylar seta apically slightly enlarged; ungual seta flagelliform reaching tip of outer claw (Fig. 15B). Pleopodal exopods with no trace of respiratory structures. Uropod: insertion of endopod slightly proximal to that of exopod.

Male: Pereopods 1 - 4 (Figs. 12B, 15B) merus and carpus with a brush of trifid spines on sternal margin. Pereopod 7 (Fig. 15C) ischium with sternal margin slightly sinuous. Genital papilla as in Fig. 16A. Pleopod 1 (Fig. 16B) exopod rounded, about twice as wide as long; endopod with distal part slightly bent medially, with triangular apex. Pleopod 2 (Fig. 16C) exopod triangular, with straight outer margin bearing 3 setae; endopod distinctly longer than exopod. Pleopods 3 - 5 exopod as in Fig. 16D-F.

Etymology: Latin: $b i=$ double + ocellatus $=$ having eyes. The name refers to the eye consisting of two ocelli of the same size.

Remarks: The new species belongs to the tomentosa-group of Trichorhina characterized by the presence of two noduli laterales per side on the pereonite 7 . This group includes with 


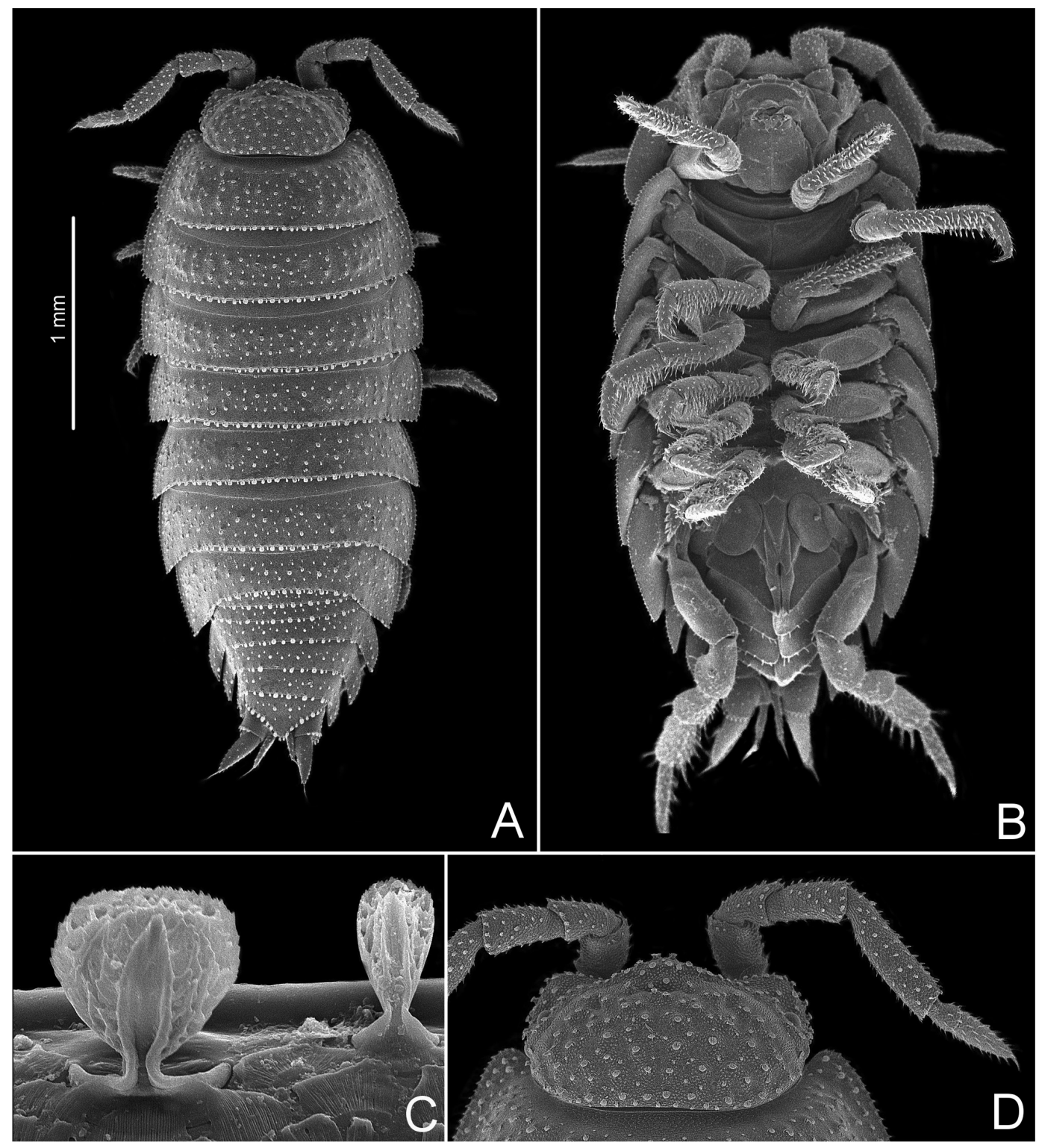

Fig. 12. Trichorhina biocellata n. sp. specimens from Playa Pita. A. Adult female in dorsal view; B. Adult male in ventral view; C. Dorsal scale-setae ()); D. Cephalon, dorsal ( + ).

certainty T. tomentosa (Budde-Lund, 1893), T. heterophthalma Lemos de Castro, 1964, both widespread in the tropics, and T. guanophila Souza-Kury, 1993 from Brazil. The new species is readily distinguished from all these species by the eye consisting of two ommatidia of equal size (one in T. tomentosa, two unequal ommatidia in $T$. heterophthalma, and five in
T. guanophila); from T. guanophila also in the male pleopod 1 exopod wider than long.

Two more species of Trichorhina are recorded from Costa Rica by Arcangeli (1930): T. giannellii Arcangeli, 1929, known also from Cuba, and T. marianii Arcangeli, 1930. From their original descriptions no information is present on the number and position of the 

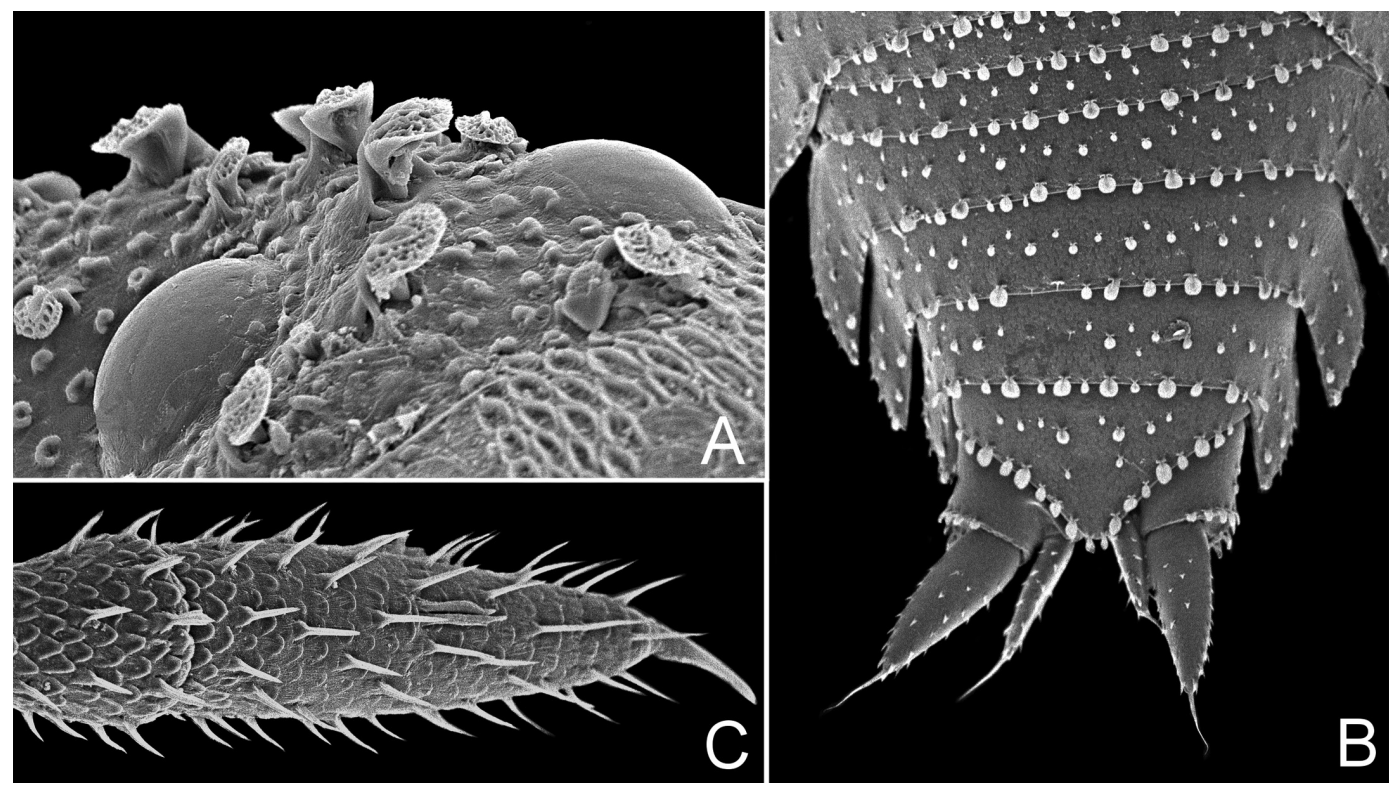

Fig. 13. Trichorhina biocellata n. sp. + from Playa Pita. A. Eye; B. Pleon, telson and uropods, dorsal; C. Antennal flagellum.

noduli laterales, so we do not know if they belong to the tomentosa-group. Trichorhina biocellata $\mathrm{n}$. sp. differs from these two species in the eye with only two ommatidia (four or five in T. giannellii and 10 in T. marianii).

\section{DISCUSSION}

In the present study seven species of terrestrial isopods are recorded from sandy and rocky shores of both coasts of Costa Rica. Three species (Buchnerillo neotropicalis, Hawaiioscia nicoyaensis and Trichorhina biocellata) are described as new and two species (Tylos niveus and Armadilloniscus cf. caraibicus) represent new records for Costa Rica. The total number of Oniscidean species presently known from Costa Rica increases from 25 to 30 (Table 1).

Six species are strictly littoral, halophilic: L. baudiniana, T. wegeneri, T. niveus, B. neotropicalis n. sp., A. cf. caraibicus, and $H$. nicoyaensis n. sp. All these species, with the exception of $H$. nicoyaensis and $B$. neotropicalis, occur on both the Pacific and Caribbean coasts of Costa Rica or in other countries along the Atlantic coast of the Americas. No morphological differences could be detected from the Pacific and Caribbean populations of these species; only A. cf. caraibicus from Playa Pita on the Pacific coast showed small differences in the less developed dorsal ornamentation, even if of the same type, from the original specimens described from the Caribbean coast of Venezuela. It will be quite interesting to check both the Pacific and Caribbean populations of these five species with molecular markers to see if there is a criptic diversity between them, as revealed in other littoral isopods, e.g. in Excirolana braziliensis Richardson, 1912, Cirolanidae (Hurtado et al., 2016), considering that the isthmus of Panama was definitely closed 2.8 Ma (O’Dea et al., 2016).

An interesting discovery was the new species of Hawaiioscia inhabiting the sandy shore of the Pacific side. The genus was previously known only from troglomorphic cave-dwelling 

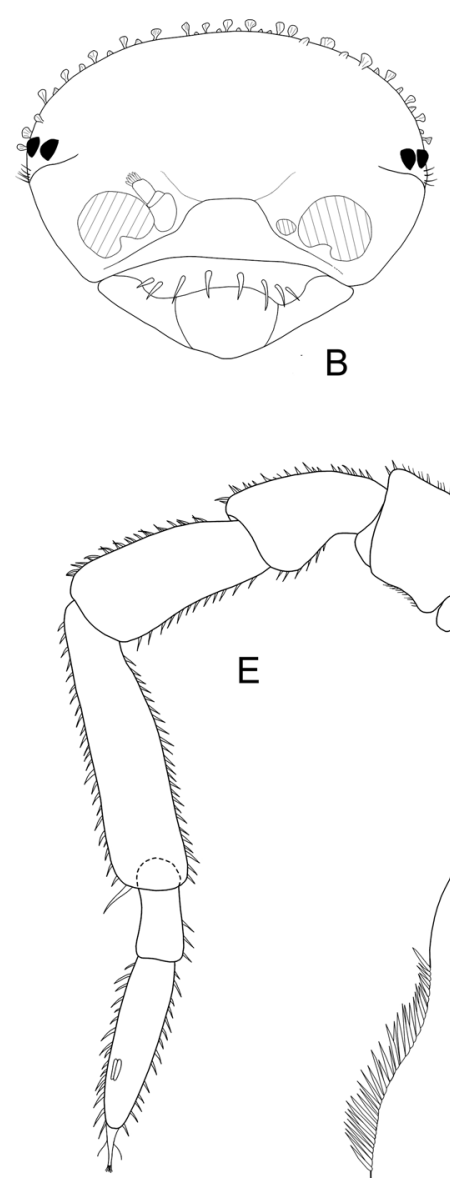

B

E
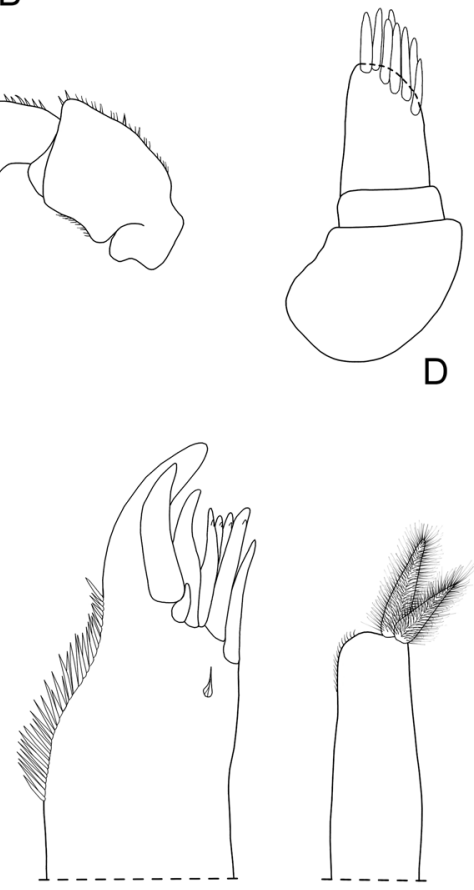

D

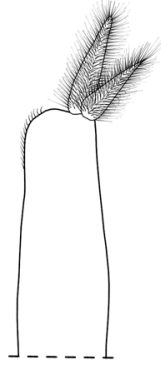

$\mathrm{H}$

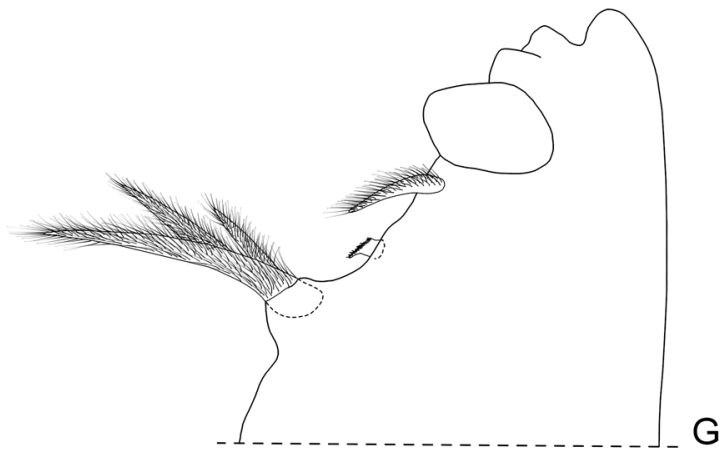

A
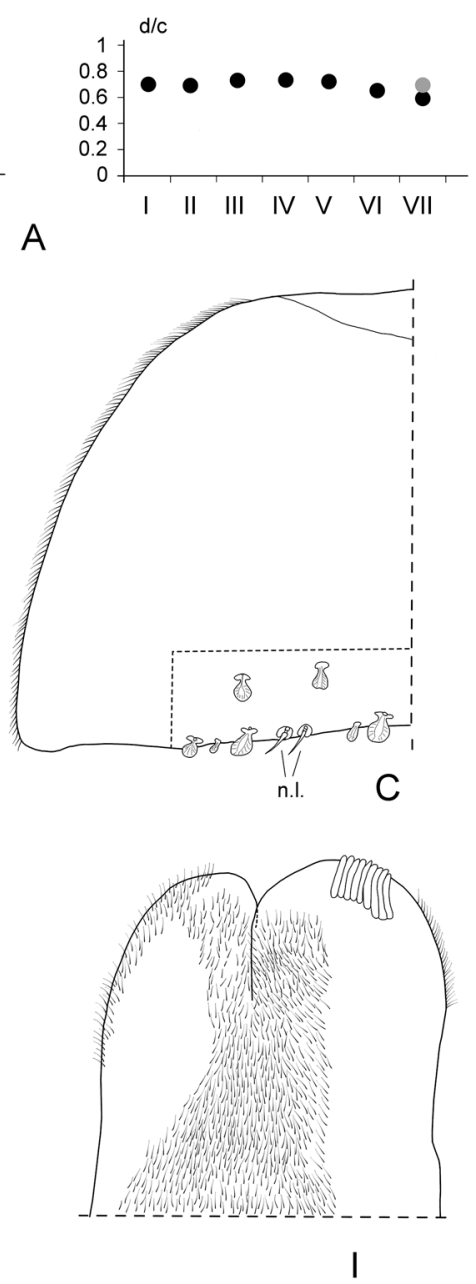

G

Fig. 14. Trichorhina biocellata $n$. sp. $\precsim$ from Playa Pita. A. B/c and d/c coordinates of noduli laterales; B. Cephalon, frontal; C. Epimeron of pereonite 7 showing noduli laterales (n.1.); D. Antennula; E. Antenna; F. Left mandible; G. Right mandible; H. Maxillula; I. Maxilla. 
species in the Hawaiian Islands and a troglophilic species from Easter Island. The number of species of Oniscidea from littoral areas of
Costa Rica will certainly increase as soon as all the coasts on both sides of the country will be properly investigated.
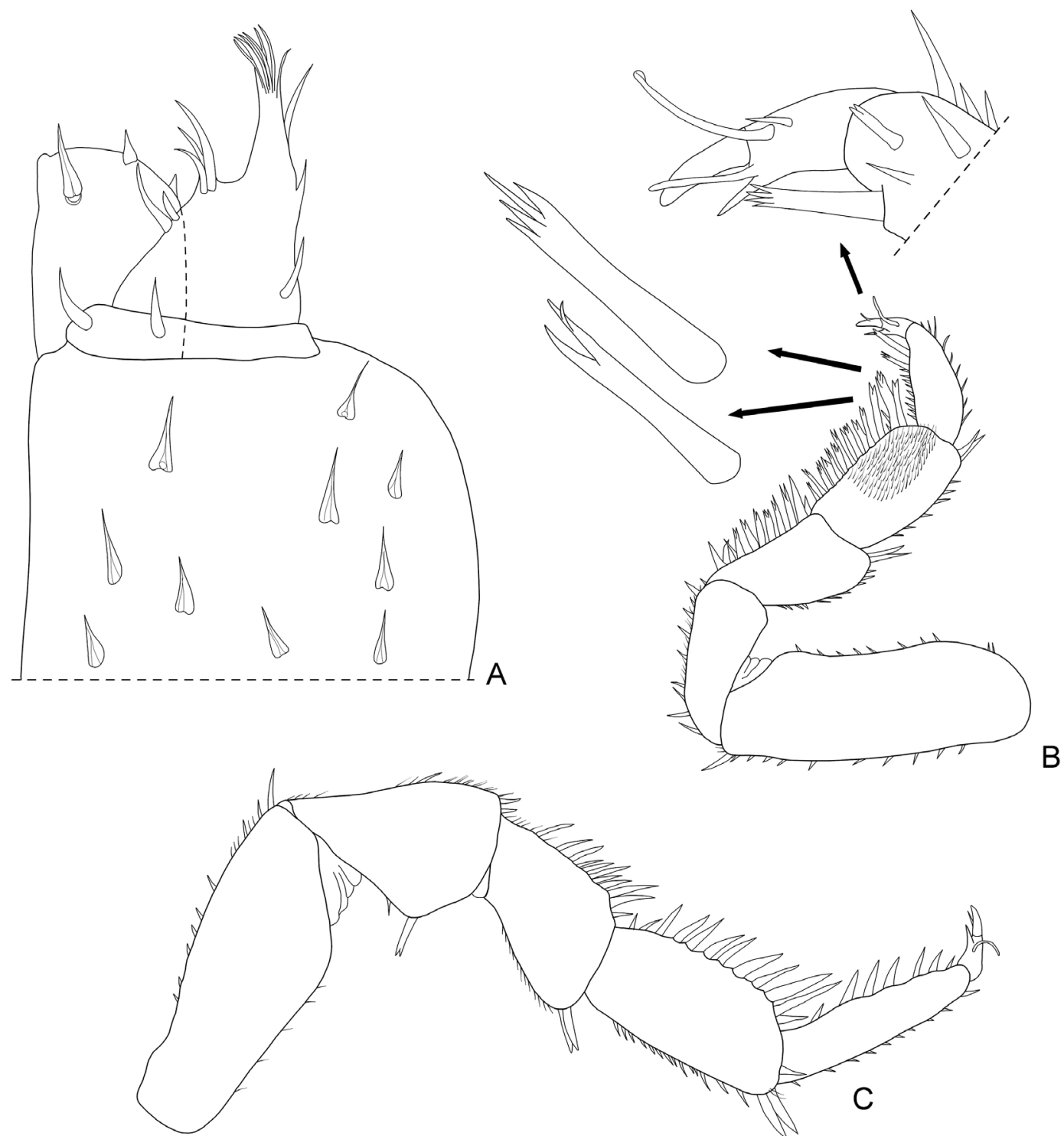

Fig. 15. Trichorhina biocellata n. sp. ô from Playa Pita. A. Maxilliped; B. Pereopod 1; C. Pereopod 7. 

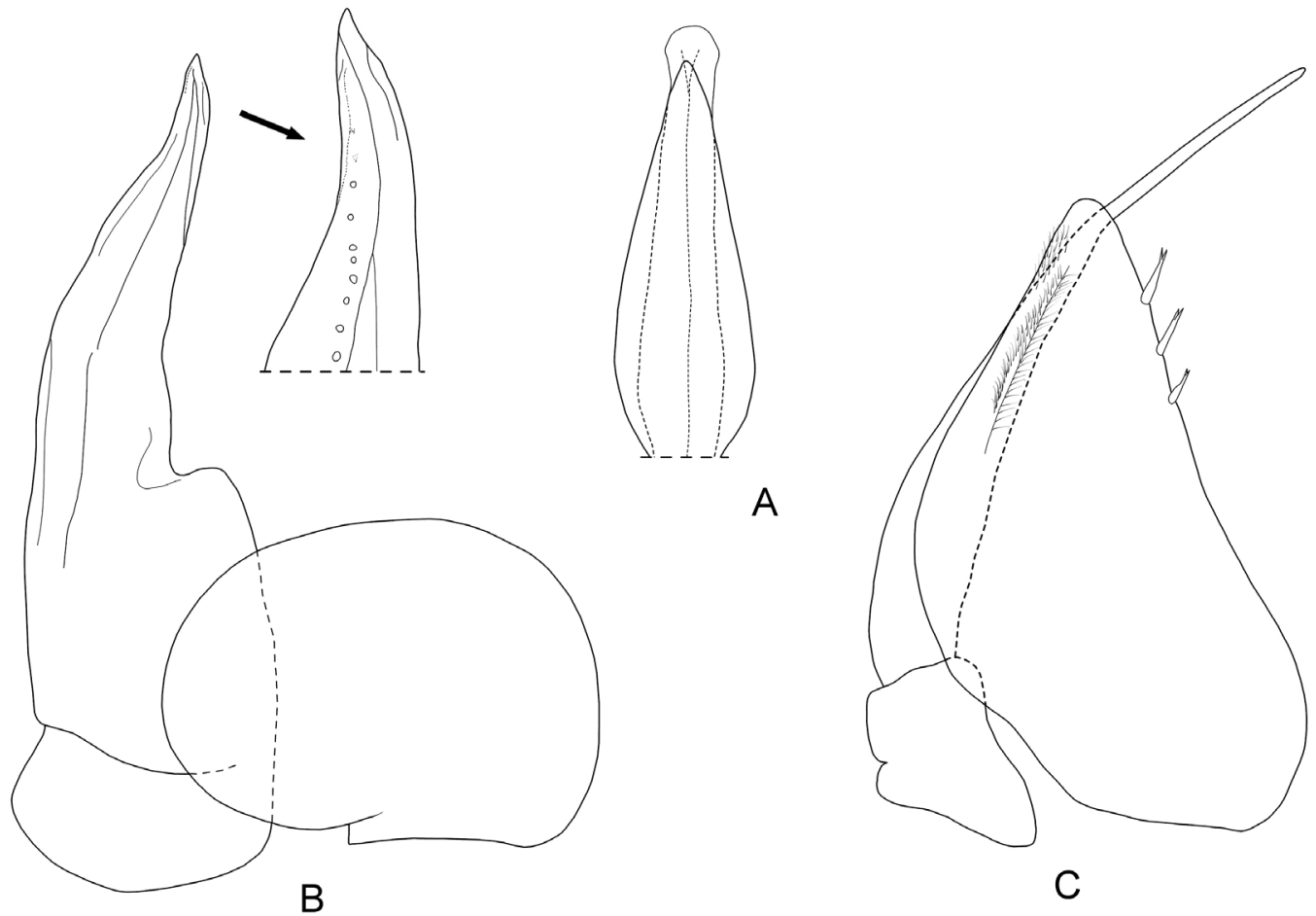

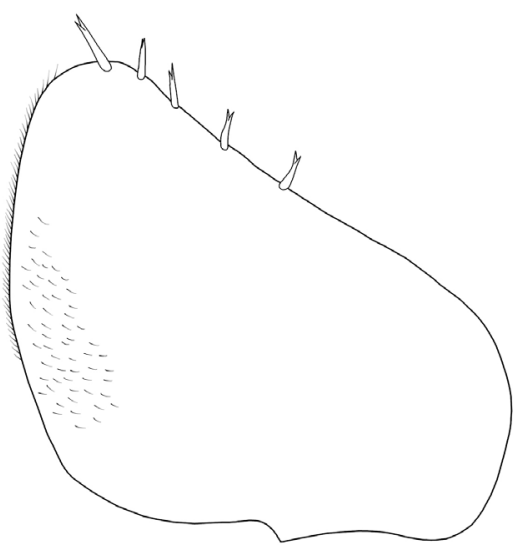

D

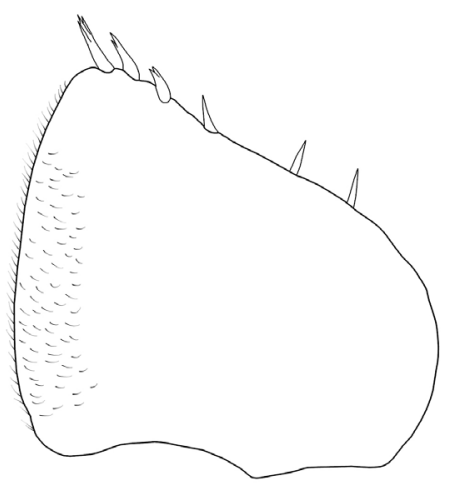

E

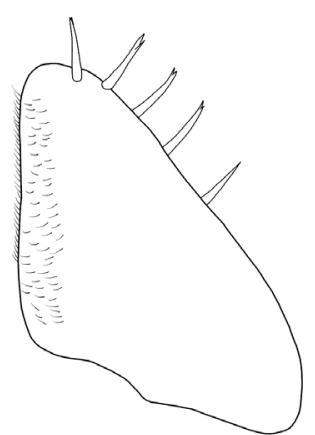

F

Fig. 16. Trichorhina biocellata n. sp. đ̊ from Playa Pita. A. Genital papilla; B. Pleopod 1; C. Pleopod 2; D. Pleopod 3 exopod; E. Pleopod 4 exopod; F. Pleopod 5 exopod. 


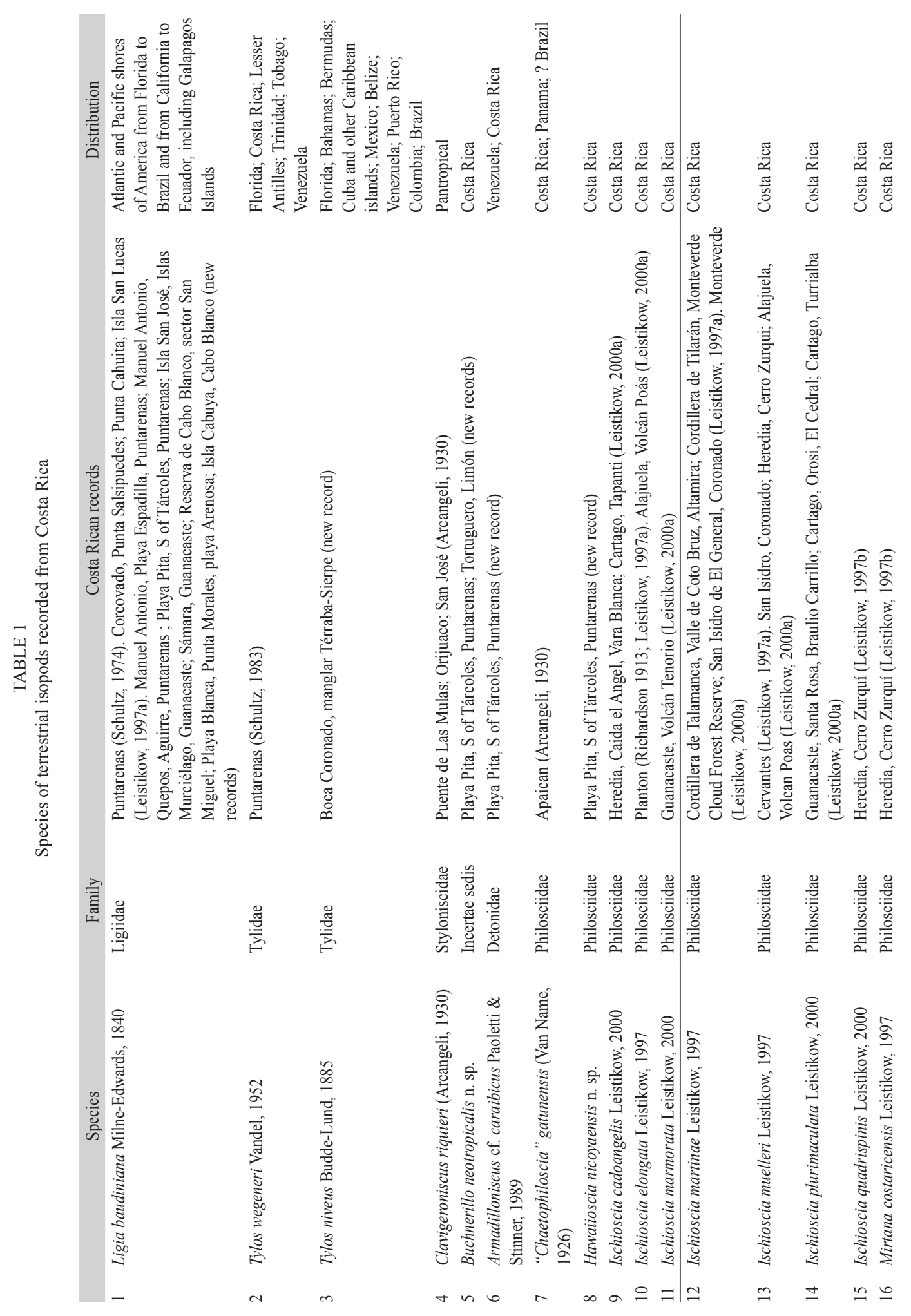




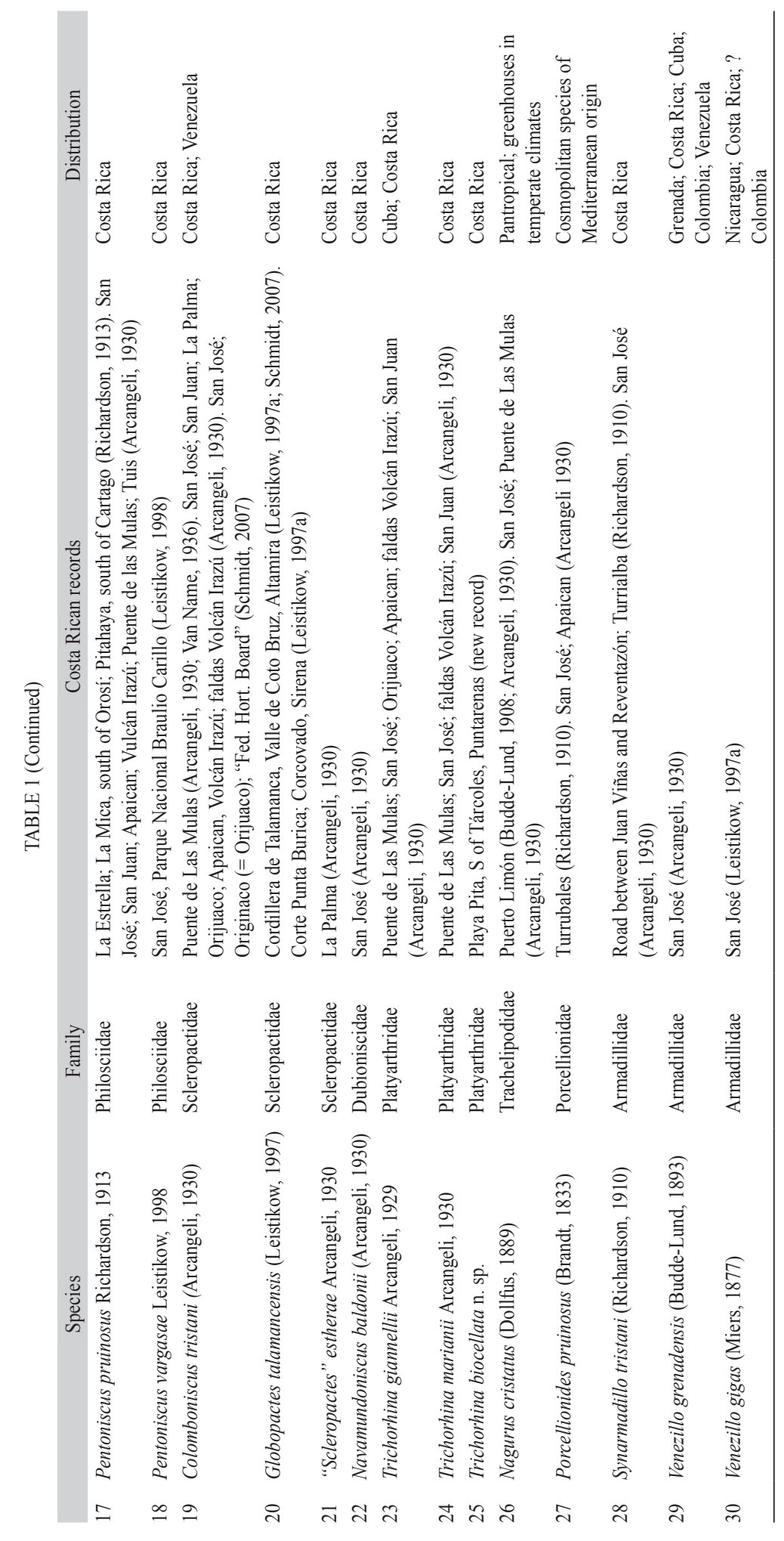




\section{ACKNOWLEDGEMENTS}

We express our sincere thanks to Rita Vargas, Curator of Crustaceans (MZUCR), and to Jeffrey Sibaja for their invaluable help in collecting part of the material here treated. We also thank Rafael Loáiciga for technical assistance with the Scanning Electron Microscope housed at CIEMIC, UCR. S.T. wishes to thank the Centro de Investigación en Ciencias del Mar y Limnlogía (CIMAR) and the University of Costa Rica for their invitation to give a talk and do research in Costa Rica at the end of 2015. Field trips and SEM access were facilitated by projects UCR-VI-808-B3-113 The benthos of Punta Morales, and UCR-VI-808-B4-117 Ecology of beaches and rocky shores of Costa Rica, both with J. Sibaja as Principal Investigator.

\section{RESUMEN}

Isopoda terrestre (Crustacea, Oniscidea) de las costas de Costa Rica, con descripciones de tres nuevas especies. Siete especies de isópodos terrestres están documentadas para las costas del Pacifico y Caribe de Costa Rica. Tres especies nuevas (Buchnerillo neotropicalis, Hawaiioscia nicoyaensis y Trichorhina biocellata) son descritas en este estudio y dos especies (Tylos niveus y Armadilloniscus cf. caraibicus) son nuevos hallazgos para Costa Rica. Se ilustra la poco conocida T. niveus. En el presente el número total de isópodos terrestres registrados para Costa Rica es de 30 especies. Es interesante que las cuatro especies típicas litorales halofílicas (Ligia baudiniana, Tylos wegeneri, $T$. niveus y $A$. cf. caraibicus) están presentes en la costa Pacífica de Costa Rica y también en el Caribe de Costa Rica y de otros países. Con excepción de $A$. cf. caraibicus, no se encontró diferencias morfológicas en poblaciones de estas especies entre el Pacifico y el Caribe de Costa Rica.

Palabras clave: Crustacea, Isopoda, Oniscidea, biodiversidad, playas, Buchnerillo, Hawaiioscia, Trichorhina, América Central.

\section{REFERENCES}

Arcangeli, A. (1927). Revisione dei generi degli isopodi terrestri. $\mathrm{I}^{\mathrm{a}}$ nota. Sopra alcuni generi di Africa e di America. Atti della Società italiana di Scienze naturali, 66, 126-141.

Arcangeli, A. (1930). Contributo alla conoscenza del "microgenton" di Costa Rica. I. Isopodi terrestri.
Bollettino del Laboratorio di Zoologia generale e agraria del Regio Istituto superiore agrario di Portici, 25, 1-29.

Arcangeli, A. (1957). I generi Diploexochus, Venezillo, Paramardillo (Crostacei Isopodi terrestri). Bollettino dell'Istituto e Museo di Zoologia dell'Università di Torino, 5, 101-142.

Carpio-Díaz , Y. M., López-Orozco, C. M., HerreraMedina, Y., Navas-S., G. R., \& Bermúdez, A. (2016). Primer registro de Tylos niveus y nuevo reporte de Porcellionides pruinosus (Oniscidea: Tylidae y Porcellionidae) para Colombia. Revista de la Academia Colombiana de Ciencias Exactas, Fisicas y Naturales, 40, 433-437.

Ferrara, F. (1974). Researches on the coast of Somalia. The shore and the dune of Sar Uanle. 3. Terrestrial isopods. Monitore zoologico italiano, Nuova Serie, $5,191-220$

Hurtado, L. A., Mateos, M., Mattos, G., Liu, S., Haye, P. A., \& Paiva, P. C. (2016). Multiple transisthmian divergences, extensive cryptic diversity, occasional long-distance dispersal, and biogeographic patterns in a marine coastal isopod with an amphi-American distribution. Ecology and Evolution, 6, 7794-7808.

Leistikow, A. (1997a). Terrestrial isopods from Costa Rica and a redescription of Ischioscia variegata (Dollfus, 1893) (Crustacea: Isopoda: Oniscidea). Canadian Journal of Zoology, 75, 1415-1464.

Leistikow, A. (1997b). Description of the terrestrial isopod Mirtana costaricensis gen. et $\mathrm{sp}$. $\mathrm{n}$. from central America (Crustacea: Isopoda: Oniscidea). Studies on neotropical Fauna and Environment, 32, 118-127.

Leistikow, A. (1998). Considerations about the genus Pentoniscus Richardson, 1913 (Crustacea: Isopoda: Oniscidea) with description of a new species. Journal of natural History (London), 32, 1339-1255.

Leistikow, A. (2000a). The terrestrial isopod genus Ischioscia in Costa Rica: New species and records, and analysis of its phylogeny (Crustacea, Isopoda, Oniscidea). Mitteilungen aus dem Museum für Naturkunde in Berlin, Zoologische Reihe, 76, 19-49.

Leistikow, A. (2000b). Terrestrial Isopoda from Guatemala and Mexico (Crustacea: Oniscidea: Crinocheta). Revue Suisse de Zoologie, 107, 283-323.

Leistikow, A. (2001). Phylogeny and biogeography of South American Crinocheta, traditionally placed in the family "Philosciidae" (Crustacea: Isopoda: Oniscidea). Organisms, Diversity \& Evolution 1, 4, 1-85.

Leistikow, A., \& Wägele, J. W. (1999). Checklist of the terrestrial isopods of the new world (Crustacea, Isopoda, Oniscidea). Revista brasileira de Zoologia, 16, 1-72. 
Montesanto, G. (2015). A fast GNU method to draw accurate scientific illustrations for taxonomy. ZooKeys, $515,191-206$.

Montesanto, G. (2016). Drawing setae: a GNU way for digital scientific illustrations. Nauplius, 24, e2016017, 6 pp.

O’Dea, A., Lessios, H. A., Coates, A. G., Eytan, R. I., Restrepo-Moreno, S. A., Cione, ... Jackson, J. B. C. (2016). Formation of the Isthmus of Panama. Science Advances, 2, e1600883.

Paoletti, M. G., \& Stinner, B. (1989). Two new terrestrial Isopoda from coralline cays of Venezuela's Caribbean coast. Proceedings of the Entomological Society of Washington, 91, 71-80.

Richardson, H. (1910). Terrestrial isopods collected in Costa Rica by J. F. Tristan, with descriptions of a new genus and species. Proceedings of the United StatesNational Museum, 39, 93-95.

Richardson, H. (1913). Terrestrial isopods collected in Costa Rica by Mr. PicADo, with the description of a new genus and species. Proceedings of the United States National Museum, 44, 337-340.

Schmalfuss, H. (2003). World catalog of terrestrial isopods (Isopoda: Oniscidea). Stuttgarter Beiträge zur Naturkunde, Serie A, 654, 1-341.

Schmalfuss, H., \& Vergara, K. (2000). The isopod genus Tylos (Oniscidea: Tylidae) in Chile, with bibliographies of all described species of the genus. Stuttgarter Beiträge zur Naturkunde, Serie A, 612, 1-42.

Schmidt, C. (2002). Contribution to the phylogenetic system of the Crinocheta (Crustacea, Isopoda). Part 1. (Olibrinidae to Scyphacidae s. str.). Mitteilungen aus dem Museum für Naturkunde in Berlin (Zoologische Reihe), 78, 275-352.

Schmidt, C. (2007). Revision of the neotropical Scleropactidae. Zoological Journal of the Linnean Society, 151(Suppl. 1), 1-339.

Schultz, G. A. (1970). A review of the spieces of the genus Tylos Latreille from the New World (Isopoda, Oniscoidea). Crustaceana, 19, 297-305.
Schultz, G. A. (1973). The cavernicolous fauna of Hawaiian lava tubes, 2. Two new genera and species of blind isopod crustaceans (Oniscoidea: Philosciidae). Pacific Insects, 15, 153-162.

Schultz, G. A. (1974). Terrestrial isopod crustaceans (Oniscoidea) mainly from the West Indies and adjacent regions. I. Tylos and Ligia. Studies on the Fauna of Curaçao and other Caribbean Islands, 45, 162-173.

Schultz, G. A. (1983). Two species of Tylos from Chile, with notes on species of Tylos with three flagellar articles (Isopoda, Oniscoidea: Tylidae). Proceedings of the biological Society of Washington, 96, 675-683.

Tabacaru, I. (1993). Sur la classification des Trichoniscidae et la position systématique de Thaumatoniscellus orghidani Tabacaru, 1973 (Crustacea, Isopoda, Oniscidea). Travaux de l'Institut de Spéologie «Émile Racovitza», 32, 43-85.

Taiti, S. (2014). The terrestrial Isopoda (Crustacea, Oniscidea) of the Maldives. Tropical Zoology, 27, 9-33.

Taiti, S., \& Ferrara, F. (1991). Terrestrial Isopods (Crustacea) from the Hawaiian Islands. Occasional Papers of the Bishop Museum, 31, 202-227.

Taiti, S., \& Howarth, F. (1997). Terrestrial isopods (Crustacea, Oniscidea) from Hawaiian caves. Mémoires de Biospéologie, 24, 97-118.

Taiti, S., \& Wynne, J. J. (2015). The terrestrial Isopoda (Crustacea, Oniscidea) of Rapa Nui (Easter Island), with descriptions of two new species. In S. Taiti, E. Hornung, J. Štrus \& D. Bouchon (Eds.). Trends in Terrestrial Isopod Biology. ZooKeys, 515, 27-49.

Vandel, A. (1952). Étude des isopodes terrestres récoltés au Vénézuela par le Dr. G. Marcuzzi suivie de considérations sur le peuplement du Continent de Gondwana. Memorie del Museo civico di Storia naturale di Verona, 3, 59-203.

Vandel, A. (1960). 64. Isopodes terrestres (première partie). Faune de France, 64, 1-416.

Van Name, W. G. (1936). The American land and freshwater isopod Crustacea. Bulletin of the American Museum of Natural History, 71, 1-535. 